\title{
MAPEAMENTO DA PRODUTIVIDADE NA COLHEITA MECANIZADA DO CAFÉ
}

\author{
Juliano Crivelenti Garcia Leal
}

Dissertação apresentada à Escola Superior de Agricultura "Luiz de Queiroz", Universidade de São Paulo, para obtenção do título de Mestre em Agronomia, Área de Concentração: Máquinas Agrícolas.

Piracicaba

Estado de São Paulo-Brasil

Maio-2002 


\title{
MAPEAMENTO DA PRODUTIVIDADE NA COLHEITA MECANIZADA DO CAFÉ
}

\author{
Juliano Crivelenti Garcia Leal \\ Engenheiro Agrônomo
}

Orientador: Prof. Titular LUIZ ANTONIO BALASTREIRE

Dissertação apresentada à Escola Superior de Agricultura "Luiz de Queiroz", Universidade de São Paulo, para obtenção do título de Mestre em Agronomia, Área de Concentração: Máquinas Agrícolas.

Piracicaba

Estado de São Paulo-Brasil

Maio-2002 
Dados Internacionais de Catalogação na Publicação (CIP)

DIVISÃO DE BIBLIOTECA E DOCUMENTAÇÃO - ESALQ/USP

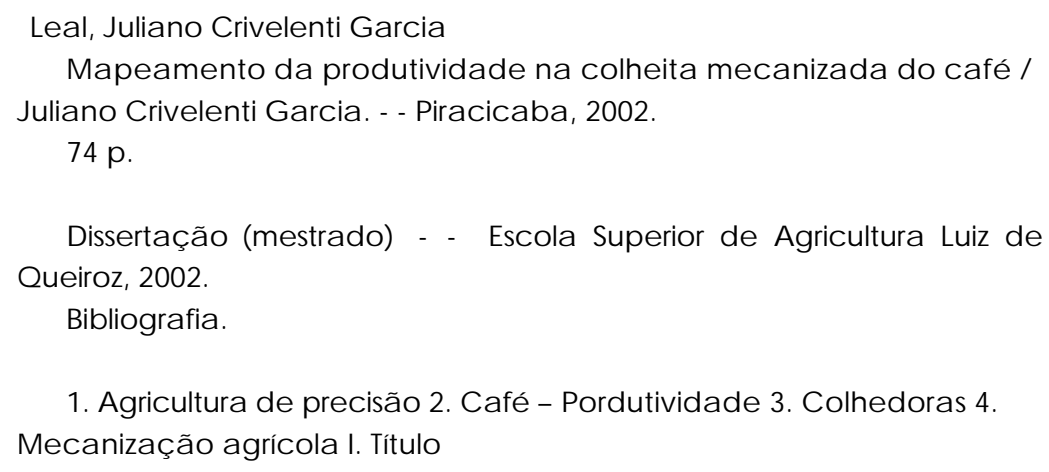

CDD 633.73

"Permitida a cópia total ou parcial deste documento, desde que citada a fonte - $\mathrm{O}$ autor" 
Dedico:

Aos meus pais: Maria Etelvina C.G.Leal e Altino Garcia Leal pelo incentivo e reconhecimento do meu empenho para que minha carreira acadêmica chegasse até onde chegou,

e

as

minhas Irmãs, Janine e Gerusa.

Com o meu carinho. 


\section{AGRADECIMENTOS}

A Deus, por todas as coisas que a vida nos mostra para que possamos crescer como pessoa, ajudando, de alguma forma, a Criação Divina.

Ao Professor Titular Luiz Antonio Balastreire, pela orientação neste trabalho e pela amizade demonstrada em todas as fases desta dissertação.

Aos Professores Drs. Thomaz Caetano C. Rípoli, Paulo Sérgio Graziano Magalhães e José Laércio Favarim, pelas sugestões conferidas para o aprimoramento deste trabalho.

Ao Departamento de Engenharia Rural da ESALQ/USP, pelos suportes pessoal e técnico.

À Fundação de Amparo à Pesquisa do Estado de São Paulo, pelo suporte financeiro.

Ao Engenheiro Eletricista Juarez Reno Amaral e ao Técnico em eletrotécnica Áureo Santana de Oliveira, do Laboratório de Instrumentação Agrícola do Departamento de Engenharia Rural da ESALQ/USP, pelo auxílio prestado na condução desta pesquisa e pela amizade.

A Evaldo Vicentine por ceder a área da Fazenda Matinha, a Marcelo Pereira da Silva e Carlos Roberto Darini, responsáveis técnicos. 
Aos amigos Fábio Henrique R. Baio, Júlio César Dalla Mora Esquerdo, Luiz Cláudio Moreira Cremonini, Marco Ripoli, Sérgio Fabrício Bizuti, pelo auxílio prestado ao longo desta pesquisa e, sobretudo, pela convivência.

Aos demais professores do Departamento de Engenharia Rural da ESALQ/USP, que contribuiram para o aprimoramento profissional de seus alunos em suas disciplinas.

Aos funcionários do Departamento de Engenharia Rural da ESALQ/USP: Fernanda Barbosa, Dona Lourdes, Luiz Afonso, Francisco de Oliveira, José Geraldo Gomes e José Ferreira de Oliveira, pelo auxílio prestado.

Aos alunos do Curso de Pós-Graduação em Máquinas Agrícolas, pela convivência ao longo desses 2 anos.

Às professoras Maria Alaide Teixeira Leal e Maria Cecília Machado Bonachella pelo auxílio e sugestão confe ridas neste trabalho.

Às bibliotecárias Eliana Maria Garcia e Silvia Zinsly, pelo auxílio na organização das referências bibliográficas.

A todos aqueles que, de alguma forma, contribuíram para a realização deste trabalho, muito obrigado. 


\section{SUMÁRIO}

Página

LISTA DE FIGURAS ........................................................................... viii

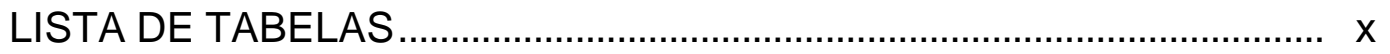

LISTA DE QUADROS …………………………..............................

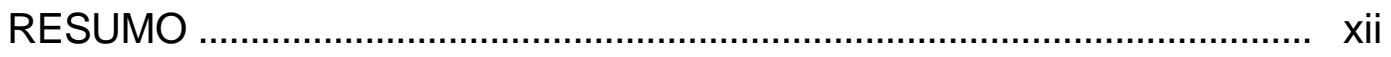

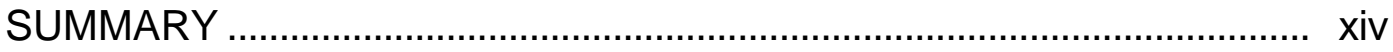

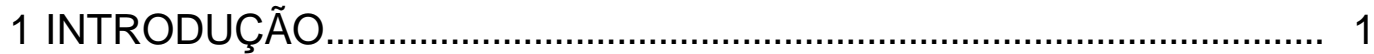

2 REVISÃO DE LITERATURA ................................................................... 3

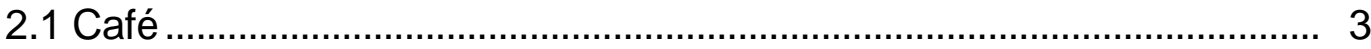

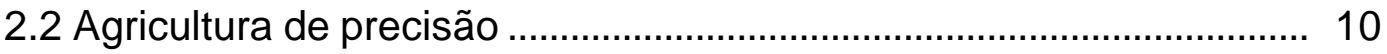

2.3 Sistema de posicionamento globatGPS …….................................... 12

2.4 Mapa de produtividade .................................................................. 16

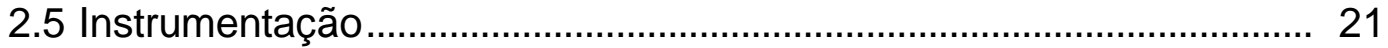

2.6 Sistemas de informações geográficas-SIG ........................................ 23

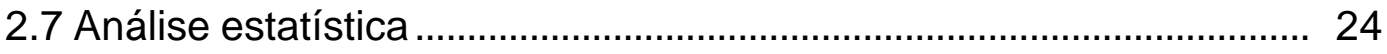

2.7.1 Estatística descritiva ................................................................ 24

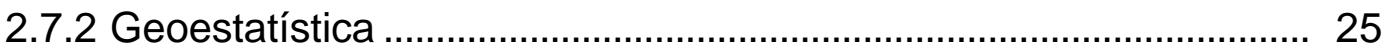

2.7.2.1 Semivariograma ................................................................... 27

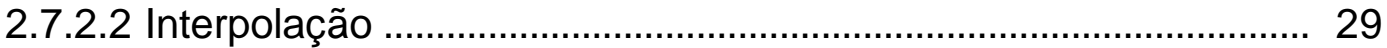

3 MATERIAL E MÉTODOS …............................................................. 31

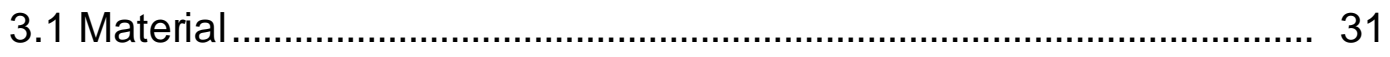

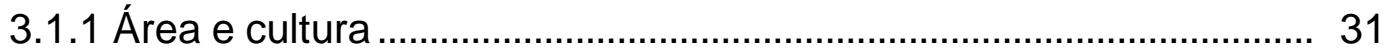

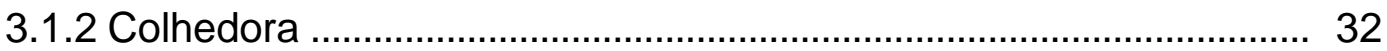




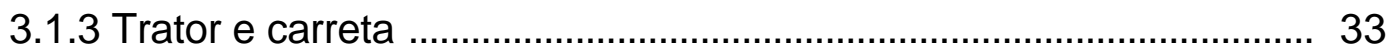

3.1.4 Sistema automático de pesagem ..................................................... 34

3.1.5 Sistema de posicionamento global diferencial (DGPS) ................. 35

3.1.6 Sistema de aquisição de dados ................................................... 38

3.1.7 Programas utilizados .............................................................. 39

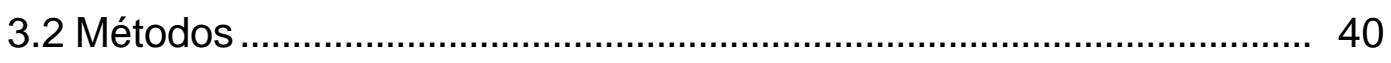

3.2.1 Aquisição e armazenamento dos dados de posição da colhedora e massa do material colhido............................................................ 40

3.2.2 Calibração do sistema automático de pesagem ............................. 40

3.2.3 Correção de posicionamento em função do tempo de atraso no processamento do material colhido ................................................ 42

3.2.4 Determinação do ponto representativo do centro das células ....... 43

3.2.5 Cálculo da produtividade .............................................................. 43

3.2.6 Análise dos dados ....................................................................... 45

3.2.6.1 Análise estatística descritiva ................................................... 45

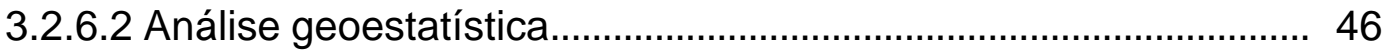

3.2.7 Geração do mapa de produtividade ............................................... 47

4 RESULTADOS E DISCUSSÃO...................................................... 48

4.1 Sistema de medição da produtividade - calibração estática.............. 48

4.2 Sistema de medição da produtividade - calibração dinâmica ........... 49

4.3 Correção de posicionamento em função do tempo de atraso............ 50

4.4 Aquisição dos dados de posição e massa ............................................ 51

4.5 Massa acumulada de material colhido .............................................. 52

4.6 Análise estatística descritiva dos dados ............................................ 53

4.7 Análise geoestatística dos dados de massa ..................................... 54

4.8 Mapeamento da produtividade da cultura do café ............................... 55

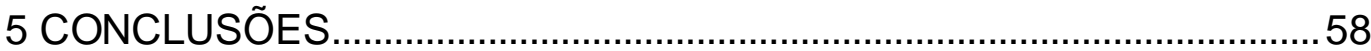

5.1 Sugestões para estudos futuros ....................................................... 59

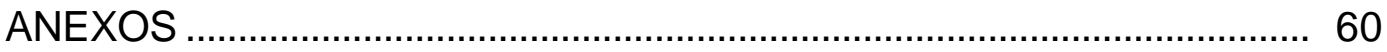

REFERÊNCIAS BIBLIOGRÁFICAS ...................................................... 63 


\section{LISTA DE FIGURAS}

Página

1 Maiores produtores mundiais de café de 2001 ................................... 3

2 Maiores estados brasileiros produtores de café na safra 2001........... 4

3 Relação entre a produção e o consumo mundial ................................... 5

4 Gráfico do estoque mundial de café ..................................................... 6

5 Gráfico da área total brasileira e o número de plantas......................... 7

6 Ilustração das áreas de cafeicultura de maior expressão econômica no Estado de São Paulo ........................................................................... 8

7 Semivariograma e seus componentes ............................................... 28

8 Vista da área experimental onde foi realizado o ensaio da colheita mecanizada do café ............................................................................ 32

9 Vista da colhedora utilizada na operação de colheita ............................ 33

10 Carreta e trator utilizados no projeto .................................................. 33

11 Estrutura de ferro com as células de carga e "bigbag" utilizadas no sistema automático de pesagem ..................................................... 34

12 Operação de descarregamento dos grãos de café no "bigbag" ........ 35

13 Constituintes do DGPS utilizado para o posicionamento da colhedora no campo ...................................................................... 36

14 Operação de colheita no campo experimental ..................................... 37

15 Diagrama do DGPS, sistema de pesagem e sistema de aquisição de dados utilizados no projeto ......................................................... 37

16 Base estacionária com o receptor GPS fixo montada no campo ....... 38 
17 Determinação do ponto representativo do centro da célula

18 Curva de calibração obtida para o sistema de medição da produtividade, durante o carregamento e descarregamento

19 Representação da massa acumulada no interior do "bigbag" em função da distância percorrida pela colhedora. Massa média obtida em intervalos constantes de 10 metros, para uma passada... 52

20 Histograma dos dados de massa ......................................................... 53

21 Semivariograma experimental, mostrando o modelo ajustado para os dados de massa ........................................................................ 54

22 Mapa de isolinhas de produtividade da cultura de café ...................... 56 


\section{LISTA DE TABELAS}

Página

1 Custos comparativos: sistema manual e mecanizado ............................ 9

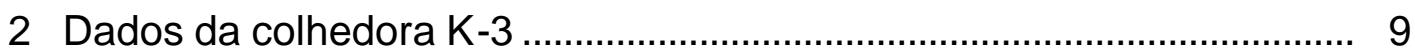

3 Resultados da análise estatística do ensaio da calibração dinâmica para os dados................................................................................. 50

4 Dados do ensaio para a determinação do tempo de atraso dos grãos colhidos ............................................................................. 50

5 Parte de uma planilha do Excel gerada pelo sistema de aquisição de posição e massa................................................................................ 51

6 Valores estatísticos dos dados de massa colhida da área

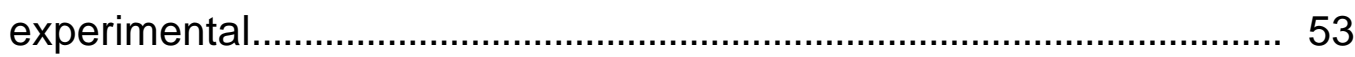

7 Parâmetros do modelo do semivariograma ajustado .............................. 54

8 Exemplos de dados de posição e produtividade para algumas células, para obtenção de um mapa de produtividade ............................ 55 


\section{LISTA DE QUADROS}

Página

1 Produtividade média brasileira ponderada por faixa etária das

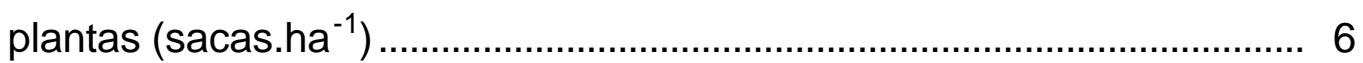

2 Ilustração da parte de uma planilha original do Excel utilizada para o cálculo de produtividade............................................................... 45 


\title{
MAPEAMENTO DA PRODUTIVIDADE NA COLHEITA MECANIZADA DO CAFÉ
}

\author{
Autor: JULIANO CRIVELENTI GARCIA LEAL \\ Orientador: Prof.Titular. LUIZ ANTONIO BALASTREIRE
}

\section{RESUMO}

A adoção da Agricultura de Precisão é crescente na agricultura brasileira. É notório o aumento de informações e aplicações desses conceitos, porém, para culturas perenes que não possuem importância econômica nos Estados Unidos e em outros países desenvolvidos, não são realizadas pesquisas e informações suficientes para a obtenção de soluções tecnológicas viáveis, que possam ser aplicadas na geração de mapas de produtividade para o monitoramento da produção. A Agricultura de Precisão baseia-se no conhecimento e no gerenciamento da variabilidade espacial dos fatores de produção, sendo que o mapeamento da produtividade das culturas é considerado uma das etapas fundamentais e indispensáveis. Este trabalho teve como objetivo o mapeamento da produtividade na colheita mecanizada do café por meio da adaptação, construção e utilização de um sistema automático de pesagem de grãos, constituído de uma estrutura de ferro apoiada sobre quatro células de carga e suportando um "bigbag" utilizado como depósito dos grãos colhidos. Um sistema de posicionamento global diferencial (DGPS) foi utilizado na colhedora para o posicionamento 
georreferenciado, sendo o sinal de correção diferencial recebido por meio de ondas de rádio.O sistema utilizado permitiu a obtenção do mapa de isolinhas da produtividade do café, em uma área de 4 ha. A produtividade média da área foi de $4226 \mathrm{~kg} \cdot \mathrm{ha}^{-1}$, sendo a menor produtividade de 1284 $\mathrm{kg} \cdot \mathrm{ha}^{-1}$, e a produtividade máxima de $6326 \mathrm{~kg} \cdot \mathrm{ha}^{-1}$. As principais vantagens do sistema automático de pesagem utilizado neste trabalho referem-se à possibilidade da obtenção direta do peso dos grãos de café, sem que haja necessidade da utilização de sensores para a determinação da umidade e densidade do material colhido e a facilidade e simplicidade de calibração do sistema.

PALAVRAS CHAVES: Agricultura de Precisão; Mapeamento da Produtividade; Célula de Carga; DGPS. 


\title{
COFFEE YIELD MAP
}

\author{
Author: JULIANO CRIVELENTI GARCIA LEAL \\ Adviser: Prof. LUIZ ANTONIO BALASTREIRE
}

\section{SUMMARY}

The adoption of the Precision Agriculture concepts has been growing in Brazil. Precision Agriculture is based on the knowledge and management of space variability of all production factors. The yield mapping is considered an essential and indispensable step in the process to optimize production through application of crop information and advanced technology. The objetive of this research was to obtain a yield map for a coffee crop an automatic weighing system, by adapting, constructing and using the system was made of a steel structure supported by four load cells containing a big bag, which served as a grain tank. A real time DGPS was used with a rover antena and a GPS recever on the harvester and a base antenna and GPS recever to calculate the differential correction signal, wich was received by an FM radio.With this system the yield map for a coffee crop was obtained for an area of 4 ha. The average yield of the area was $4226 \mathrm{~kg} \mathrm{ha}^{-1}$, the lowest and highest productivities were $1284 \mathrm{~kg} \cdot \mathrm{ha}^{-1}$ and $6326 \mathrm{~kg} \cdot \mathrm{ha}^{-1}$ respectively.The main advantages of the automatic weighing system developed in this study were the possibility of direct obtaining the coffee beans weight without the need of sensors to determine the moisture or density of the harvested material, and the easyness and simplicity to calibrate the system. 


\section{INTRODUÇÃO}

Com o processo da globalização e suas consequências, como o aumento da competitividade, passa a ser fundamental a adoção de novas tecnologias para o sucesso de qualquer atividade agrícola.

Entre as tecnologias e conceitos que surgiram recentemente, estão os conceitos da Agricultura de Precisão, que permitem o monitoramento da variabilidade espacial das culturas, visando a otimização da produção agrícola, a minimização do impacto ambiental, provocados pela utilização de insumos agrícolas e a redução dos custos de produção.

No Brasil, a Agricultura de Precisão está sendo adotada gradativamente, revolucionando o modo de gerenciamento das propriedades rurais. Por se tratar de novos conceitos, tais como: mapas de produtividade, mapas de atributos de solos e plantas e a aplicação localizada de insumos, urge a necessidade de se fazer pesquisas nesta área para que os mesmos sejam adotados dentro da realidade brasileira.

O café é uma das culturas mais importantes no Brasil, sendo o maior produtor mundial, com $27 \%$ da produção total (safra 2001) e, apesar da importância desta cultura para a agricultura brasileira, os conceitos da Agricultura de Precisão ainda não foram adotados para ela (Agrianual 2001).

Este trabalho teve como objetivo a elaboração de um mapa de produtividade na colheita mecanizada do café e de analisar a variabilidade espacial desta cultura, visando o seu gerenciamento localizado e o 
aproveitamento do potencial daqueles conceitos para 0 aumento da produtividade e a utilização mais racional dos insumos. 


\section{REVISÃO DE LITERATURA}

\subsection{Café}

Como relata Zafalon (1998), o café, que já representou $70 \%$ das receitas brasileiras com a exportação, na década de 50 , é a segunda "commodity" do mundo nas transações internacionais, perdendo somente para o petróleo. Produzido em 57 países, as receitas do café com as exportações mundiais somam US $\$ 15$ bilhões por ano e, somando os negócios internos desses países, o valor sobe para US $\$ 50$ bilhões.

De acordo com os dados publicados pelo anuário Agrianual 2002, o Brasil é o maior produtor mundial de café, com 2,7 milhões de hectares de área cultivada (2000/01). A Figura 1 ilustra os maiores produtores mundiais de café na safra 2000/01.

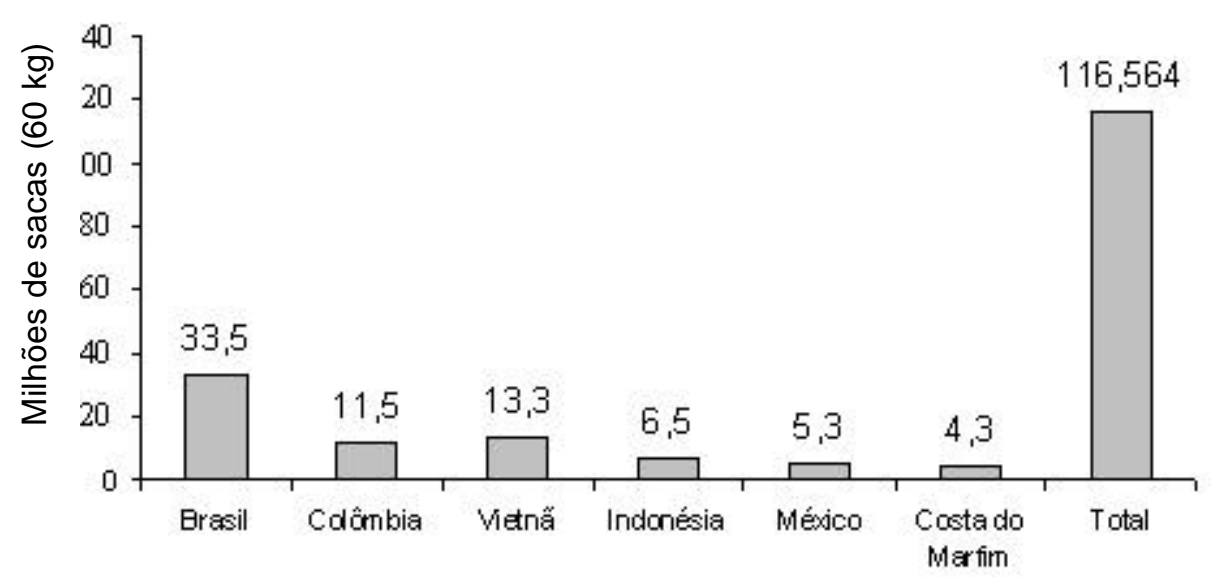

Fonte: Agrianual 2002

Figura1 - Maiores produtores mundiais de café de 2001. 
A produção brasileira de café em 2000/01 foi de 33,5 milhões de sacas de $60 \mathrm{~kg}$. A Figura 2 ilustra os maiores estados brasileiros produtores de café.

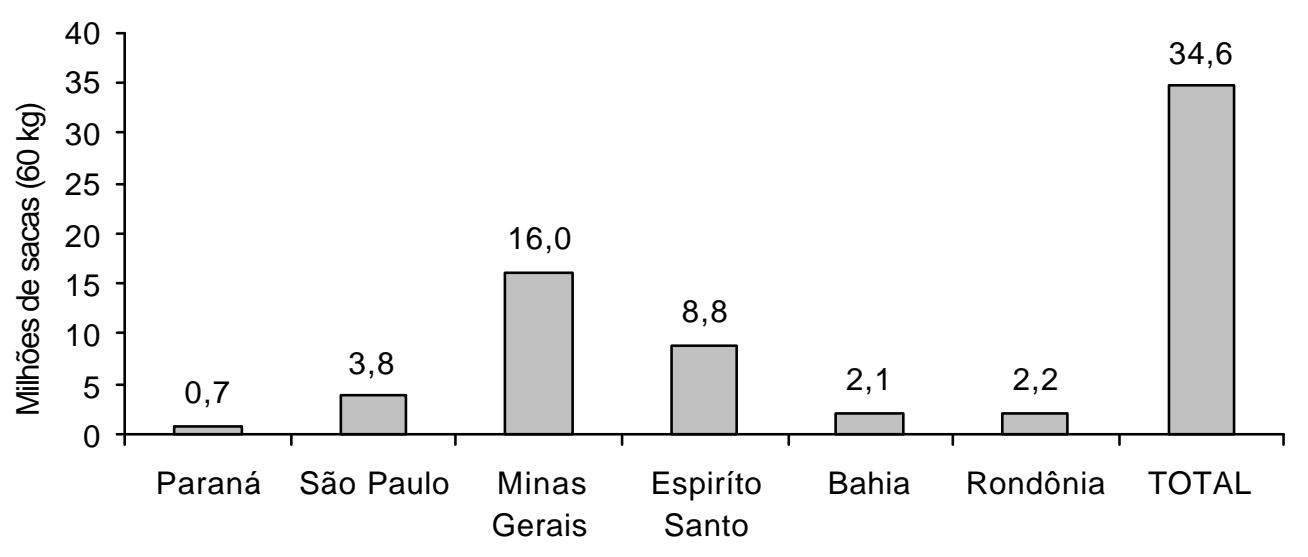

Fonte: Agrianual 2002

Figura 2- Maiores estados brasileiros produtores de café na safra 2001.

De acordo com Marino (2002) o mercado internacional de café apresenta um desequilíbrio acentuado entre a oferta e a demanda, devido ao aumento de produção em diversos países nos últimos anos. Ao contrário do aumento expressivo da produção, o consumo mundial cresceu timidamente no mesmo período. Enquanto o acréscimo da produção mundial foi de 19 milhões de sacas, o acrécimo de consumo não passou de 8 milhões de sacas. Trata-se de uma produção mundial que deverá estar acima de 10 milhões de sacas com relação ao consumo mundial para este ano safra de 2001-02 (119 milhões de sacas para 107 milhões de sacas). Será a maior diferença registrada entre produção e consumo mundial, desde o início da década passada. A Figura 3 ilustra a relação entre produção e consumo mundial. 


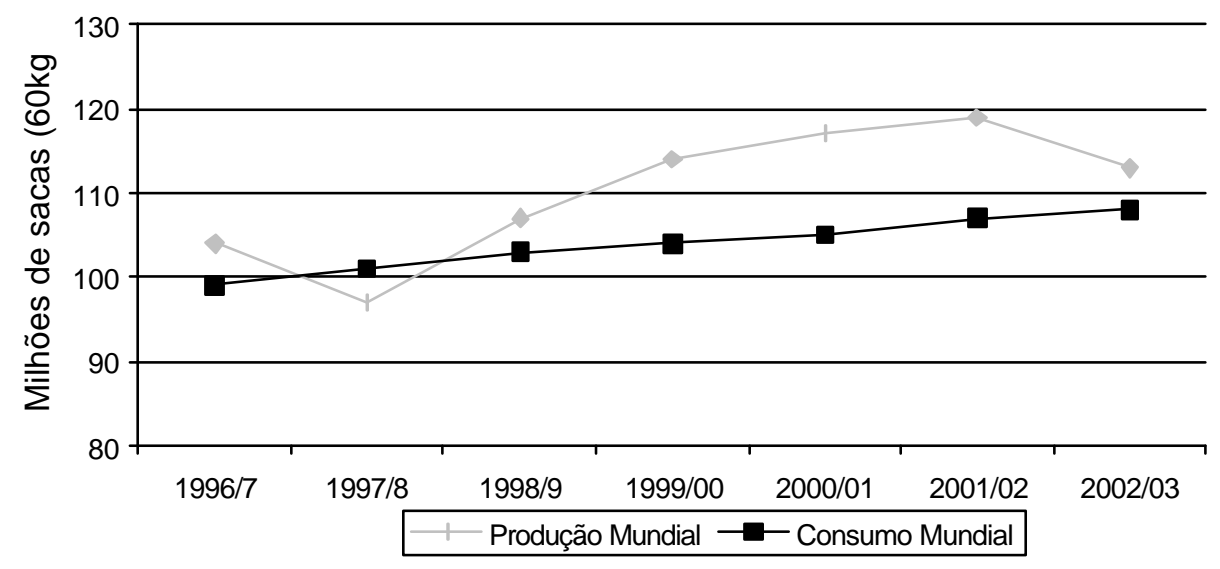

Fonte: Agrianual 2002

Figura 3- Relação entre a produção e o consumo mundial.

Ainda, segundo o mesmo autor a última crise acentuada do setor foi no ano de 1992, em que a relação entre produção e consumo revela certo equilíbrio de mercado. Contudo, a partir do ano safra 1999/2000, a diferença entre a oferta e o consumo apresentou significativa discrepância. Tal desequilíbrio se deveu ao aumento mundial desordenado da cultura, em face dos preços atraentes da "commodity" no mercado internacional, no período de 1995 a 2000. Projeta-se um cenário descendente da produção mundial, da ordem de $4,5 \%$ a $5,0 \%$ no ano safra 2002/2003. Pelo fato de que os países produtores se caracterizam pelo baixo desenvolvimento econômico, o setor deverá sofrer consequências negativas mais rapidamente. Diversos países produtores dependem diretamente do setor cafeeiro para o desenvolvimento econômico-social, sendo, em muitos casos, a única fonte significativa de renda.

Segundo o anuário Agrianual 2002 ainda que a relação entre a produção e o consumo caminhe para o reequilíbrio, o acúmulo mundial de café excedente estocado ainda será muito grande no ano-safra de 2003-2004. A Figura 4 ilustra este fato. 


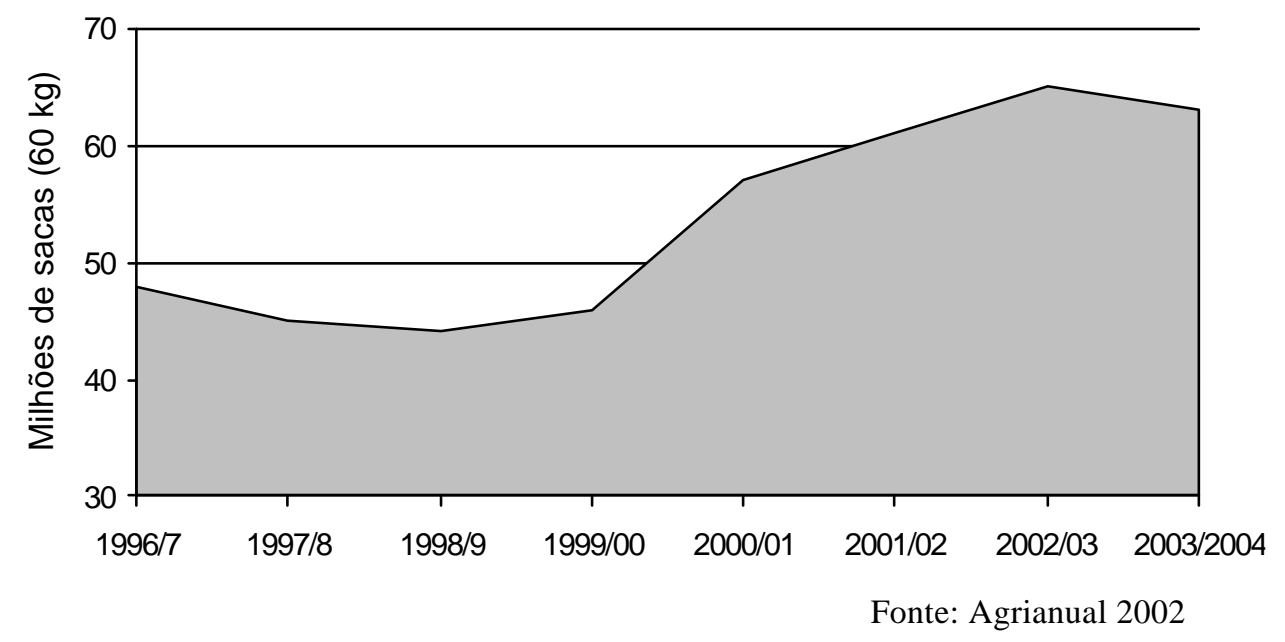

Figura 4- Gráfico do estoque mundial de café.

A produtividade média ponderada brasileira, por faixa etária das plantas (sacas. ha ${ }^{-1}$ ), fornecida pelo anuário Agrianual (2002) está ilustrada no Quadro 1.

\begin{tabular}{llllllll}
\hline Anos & $95 / 96$ & $96 / 97$ & $97 / 98$ & $98 / 99$ & $99 / 00$ & $00 / 01$ & ${ }^{*} 01 / 02$ \\
\hline 2 a 10 & 12,5 & 19,2 & 16,2 & 24,7 & 21,4 & 21,4 & 20,3 \\
11 a 20 & 8,2 & 12,6 & 10,7 & 16,2 & 14,0 & 14,1 & 13,3 \\
$>20$ & 4,8 & 7,3 & 6,2 & 9,4 & 8,1 & 8,2 & 7,8 \\
\hline Média & 8,4 & 12,9 & 10,9 & 16,6 & 14,3 & 14,4 & 13,6 \\
\multicolumn{5}{c}{ Quadro } & 1- Produtividade média brasileira ponderada por faixa etária das plantas (sacas.ha ${ }^{-1}$ )
\end{tabular}

A cafeicultura brasileira também foi fortemente influenciada pelos altos preços alcançados pela "commodity" em meados dos anos 1990. Assim, como a maior parte dos países produtores, o Brasil iniciou um processo de expansão e renovação contínua das lavouras. Além do crescimento da produção, a cafeicultura também apresentou uma evolução tecnológica, o que contribuiu para sua maior produtividade. A área cultivada aumentou em $10 \%$ do total e o número de plantas cresceu mais de $61 \%$ : foram mais 2,4 bilhões de plantas no parque cafeeiro nacional entre 1995 e 2000. Atualmente, o total de plantas cultivadas no país é da ordem de 6,3 bilhões. A Figura 5 ilustra a

* Estimativa: FNP consutoria 
tendência natural de abandono e/ou migração da atividade, devido a alta de oferta. A erradicação das lavouras deverá intensificar-se com a inviabilização econômica da atividade nos próximos anos (Agrianual 2002).

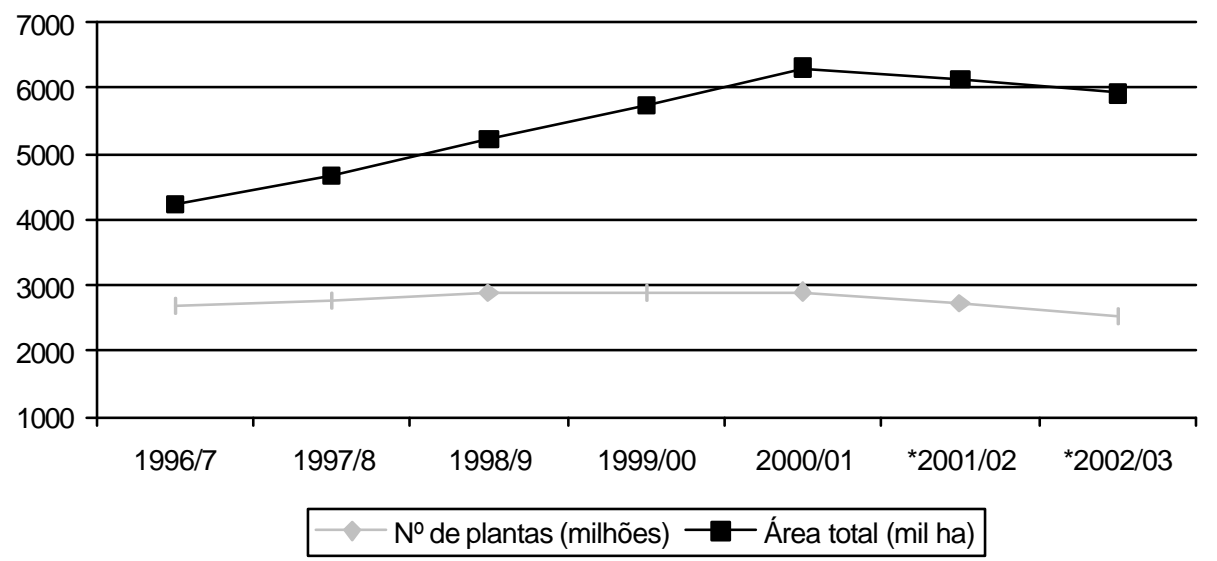

Fonte: Agrianual 2002

Figura 5- Gráfico da área total brasileira e o número de plantas.

Segundo dados do Agrianual (2001) ao contrário do Brasil, inúmeros países ainda dependem fortemente da cafeicultura para a geração de saldos na balança de comércio exterior. Em 1993, a Colômbia, maior concorrente às exportações brasileiras no mercado internacional, ainda obtinha $19,5 \%$ de sua receita cambial com as exportações de café, enquanto o Brasil, com pauta bastante diversificada de exportações, dependia do produto em apenas 3,9\%. Já na safra 96/97, a receita cambial gerada pelo café na economia nacional foi superior a US\$2,5 bilhões, correspondendo a $6 \%$ das exportações brasileiras.

De acordo com Vegro (1997) o mercado europeu constitui o principal pólo importador de café, respondendo por cerca de $62 \%$ das importações totais do produto brasileiro. Individualmente, os Estados Unidos continuam sendo os maiores importadores, com $25,5 \%$.

* Estimativa: FNP consutoria 
Em estudo realizado por Pino (1999) os autores afirmam que a cafeicultura paulista, está fundamentalmente distribuída por quatro regiões diferenciadas, tendo por pólos os municípios de: a) Franca; b) Espiríto Santo do Pinhal (São João da Boa Vista); c) Marília (Getulina e Vera Cruz); d) Pirajú. As áreas pesquisadas encontram-se exatamente sobre as principais manchas de café no Estado de São Paulo (Figura 6).

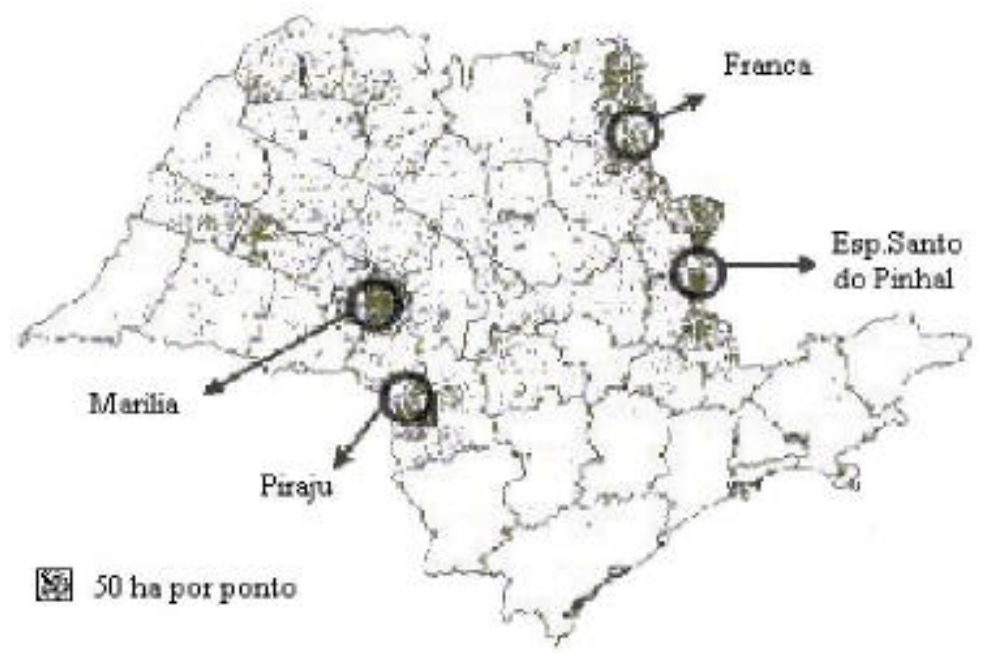

Figura 6 llustração das áreas de cafeicultura com maior expressão econômica no Estado de São Paulo.

Taglialegna \& Silveira (2000) consideram a colheita uma etapa muito importante do sistema de produção do café e recomendam que deva ser feita quando a maior parte dos frutos estiverem no estágio de cereja. Os autores salientam, entretanto, que essa uniformidade nem sempre é possível, pois, na maioria das vezes, a florada é desuniforme, fazendo com que o café colhido seja uma mistura de grãos ainda verdes, grãos em fase de cereja e grãos já secos.

Um ensaio feito por Kashima (1985) traz uma comparação de custos entre a colheita manual e mecanizada, com a colhedora K-3 (Tabela 1). Observa-se que o custo da colheita mecânica (com repasse manual) atingiu Cr $\$ 3,99$ por saca de $60 \mathrm{~L}$, correspondendo a $48 \%$ do preço que seria pago, se a 
operação fosse feita pelo sistema manual. Assim, a utilização da colhedora K-3 representou uma economia de $52 \%$ na operação de colheita.

Tabela 1. Custos comparativos: sistema manual e mecanizado.

\begin{tabular}{cc}
\hline Sistema & Cr\$/sc de 60 L. \\
\hline Manual & 8,25 \\
Mecanizado (operação + repasse manual) & 3,99 \\
\hline
\end{tabular}

Fonte: Kashima (1985)

Kashima (1985) num ensaio com a colhedora automotriz K-3, traz alguns parâmetros estudados na colheita do café (Tabela 2). A possibilidade de mecanização da colheita é a grande saída para o país continuar com a liderança mundial de café, pela competitividade nos custos e na qualidade do produto.

Tabela 2. Dados da colhedora K-3.

\begin{tabular}{ccc}
\hline Itens & Média & Desejáveis \\
\hline Rendimento da colheita: & 314 & 480 \\
Volume dia (sacas 60L) & 32 & 32 \\
Volume h (sacas 60L) & 17 & 17 \\
Produtividade (sacas ben./dia) & 5,8 & 5,8 \\
Consumo de combustível (Litro/ $\mathrm{h}^{-1}$ ) &
\end{tabular}

Fonte: Kashima (1985)

Rosa et al. (1991) através de um estudo analítico para a determinação do custo operacional da mão-de-obra e das máquinas agrícolas empregadas na realização da colheita do café, constataram que o custo de um saco colhido pelo sistema mecanizado é $80 \%$ do custo daquele colhido pelo sistema manual. 


\subsection{Agricultura de Precisão}

De acordo com Balastreire (1998) a Agricultura de Precisão é um conjunto de técnicas que permite o gerenciamento localizado de culturas.

Segundo Queiroz et al. (2000) a Agricultura de Precisão é a tecnologia cujo objetivo consiste em aumentar a eficiência, com base no manejo diferenciado de áreas na agricultura. A tecnologia, que se encontra em constante desenvolvimento, modifica as técnicas existentes e incorpora novas técnicas que fornecem ferramentas aos especialistas em manejo agrícola.

Segundo Evans et al. (1975) a Agricultura de Precisão tem como base a análise da variabilidade espacial dos fatores de produção em interação com os componentes da produção de grãos e com o clima.

Como relata Colvin et al. (1996) as tecnologias que dão suporte à Agricultura de Precisão começaram a aparecer em 1989, quando o sistema de Posicionamento Global se tornou disponível de forma limitada, e foi testado como meio de localizar equipamentos agrícolas no campo.

De acordo com Han et al. (1994) e Searcy (1995) um novo significado ao gerenciamento da produção agrícola é dado pela Agricultura de Precisão, está sendo fundamentado na existência da variabilidade espacial dos fatores de produção. O campo agrícola passa a ser visto como uma somatória de pequenas sub-áreas, tratadas individualmente e consideradas as menores unidades gerenciais a fim de que a rentabilidade econômica de cada uma delas seja incrementada.

Uma pesquisa conduzida por Fountas (1998) mostrou que 92\% dos fazendeiros ingleses que adotam a tecnologia de Agricultura de Precisão a recomendam para outros fazendeiros. A Agricultura de Precisão é uma tecnologia para ser implantada a longo prazo, mas há uma forte tendência para que seja adotada, tendo-se em vista seus resultados positivos.

Goering (1992) obteve a comprovação do aumento da produtividade agrícola apenas com a melhor alocação na aplicação dos 
fertilizantes, sem que houvesse 0 aumento da quantidade utilizada. $\mathrm{O}$ autor afirma, ainda, que o principal objetivo da Agricultura de Precisão é aplicar, de forma localizada, sementes, fertilizantes e outros insumos em função de variáveis de célula, a fim de se fazer o melhor uso das potencialidades do solo.

De acordo com Schueller (2000) o USDA (Departamento de Agricultura dos Estados Unidos) inspecionou fazendas produtoras de milho, em 16 estados, em 1996. Aproximadamente $9 \%$ representando $16 \%$ da área inspecionada medida em acres, utilizaram algum aspecto de Agricultura de Precisão. Desses $9 \%, 70 \%$ utilizaram alguma forma de amostragem do solo em malha; 54 \% utilizaram monitor de produtividade; $32 \%$ utilizaram aplicação à taxa variável de calcário ou de fertilizantes. Os usuários da produção agrícola espacialmente variável tinham probabilidade maior de cultivar mais acres, mais renda e obter maior produtividade.

Segundo Goering (1992) e Goering \& Han (1993) a Agricultura de Precisão tem sido cada vez mais utilizada, motivada por razões ambientais e econômicas e viabilizada pelo desenvolvimento tecnológico. O gerenciamento da atividade produtiva agrícola passa a ter, a partir deste momento, um novo enfoque.

De acordo com Blackmore \& Larscheid (1997) os conceitos da Agricultura de Precisão estão relacionados à variabilidade da produtividade e dos atributos do solo e das plantas. Segundo estes autores, existem três tipos de variabilidade: espacial, temporal e preditiva. A variabilidade espacial é observada ao longo do campo e pode ser facilmente constatada em qualquer mapa de produtividade ou fertilidade. A variabilidade temporal é observada quando se comparam mapas de produtividade de vários anos; a variabilidade preditiva é a diferença entre a previsão de algum fator e o que realmente aconteceu. Os autores relatam que, para gerenciar cada uma das variabilidades, é necessário entendê-las e, sobretudo, mensurá-las.

Como relata Steven \& Milar (1999) a Agricultura de Precisão visa adequar a administração agrícola às condições variadas encontradas nos 
campos. Isso se tornou possível recentemente, devido ao desenvolvimento de tecnologias que permitem monitorar e medir essas variações.

Blackmore (1994) considera que os principais benefícios da Agricultura de Precisão convergem para a diminuição dos custos de produção e redução expressiva dos riscos de poluição decorrentes das aplicações de produtos agroquímicos.

Hollands (1996) cita que no vale do "Red River" (Minessota, USA) o nível de nitrogênio varia de acordo com o relevo. Com a introdução do GPS e novos softwares de mapeamento, aplicações de nitrogênio podem ser realizadas com mais precisão e economia. Ferguson et al. (1996) comentam que as aplicações em dosagem variadas de nitrogênio tem o potencial de aumentar e eficiência do seu uso e reduzir sua perda para o ambiente.

Numa visão instrumental Clark \& Mcguckin (1996) e Strauss et al. (1998) dizem que Agricultura de Precisão envolve sistemas automáticos, basicamente compostos por micro-controladores, sensores e atuadores acoplados ao implemento agrícola pré-existente e interligado ao sistema de posicionamento global (GPS).

De acordo com Reitz \& Kutzback (1994) os sistemas mais utilizados pelas grandes empresas que comercializam produtos na área de Agricultura de Precisão são os sistemas de medição de fluxo de massa, os quais medem a quantidade de grãos colhidos através de mecanismos volumétricos.

\subsection{Sistema de Posicionamento Global - GPS}

Segundo Blitzkow (1995) o sistema GPS-NAVSTAR ("Navigation Satelite Time and Ranging") foi desenvolvido pelo Departamento de Defesa dos Estados Unidos da América. Trata-se de um sistema militar estratégico com enorme potencial para as aplicações civis. O setor civil passou a ter acesso a essa tecnologia a partir de meados da década de setenta e se tornou 
inteiramente operacional em 1993, quando universidades e instituições de pesquisa puderam, então, investigar e inclusive colaborar no aperfeiçoamento do sistema.

O GPS ("Global Positioning System") é um sistema projetado para fornecer o posicionamento instantâneo, bem como a velocidade do ponto sobre, ou próximo, à superfície da terra (Blitzkow, 1995).

Goering \& Han (1993) afirmaram que um dos problemas para a execução das atividades relacionadas com a Agricultura de Precisão referia-se às limitações dos sistemas terrestre de navegação. Um sistema de navegação via satélite denominado Sistema de Posicionamento Global ("Global Positioning System -GPS"), representava a mais promissora solução para o problema da navegação, à época.

De acordo com Krüger et al. (1994) dois distintos e independentes sistemas de navegação via satélite estavam em desenvolvimento. Um destes sistemas, denominado "GLONASS", estava sendo desenvolvido pelos países formadores da antiga União Soviética. O outro sistema, muito mais difundido, denominava-se "NAVSTAR Global Positioning System", mais conhecido como GPS, desenvolvido pelos Estados Unidos. Os autores relataram com detalhes o princípio de funcionamento de cada um dos sistemas, fazendo uma breve comparação entre eles, e concluíram que ambos os sistemas possuiam excelentes capacidades de determinação de posição com boa acurácia, em tempo real, sob quaisquer condições climatológicas, sem interrupções e para um número ilimitado de usuários.

Como relata Danna (1994) o sistema NAVSTAR é constituído por 24 satélites, sendo 21 ativos e 3 reservas. Estes satélites são específicos para o Sistema de Posicionamento Global (GPS) e estão dispostos de tal maneira que, a qualquer hora e em qualquer lugar do mundo, pelo menos quatro satélites estarão disponíveis para utilização. Para isso, foram criadas 6 órbitas espaçadas de $60^{\circ}$ cada uma, onde os satélites estão posicionados a $20.200 \mathrm{~km}$ de altitude. 
Blitzkow (1995) também relata que, de uma maneira simplificada, o posicionamento por meio de GPS é baseado na triangulação entre os satélites que possuem coordenadas conhecidas em suas órbitas e o receptor GPS. Para a realização desta triangulação, o receptor de GPS determina a distância receptor-satélite por equações que consideram o período de tempo entre a emissão do sinal de rádio, a partir de sua saída do satélite, e a recepção deste sinal pelo transmissor.

De acordo com (Blitzkow, 1995 \& Lange, 1996) o GPS calcula as coordenadas do ponto de acordo com uma superfície de referência, chamada de elipsóide. O sistema GPS utiliza o datum WGS 84 ("World Geodetic System" 1984). O "datum" é o conjunto de vértices de triangulação referenciais nos quais o elipsóide é ajustado. O elipsóide de referência para o "datum" WGS 84 é o GRS 80 (“Global Reference System" 1980).

Baio et al. (1998) citam como as principais fontes de erros para o posicionamento do sistema GPS: a disposição geométrica dos satélites, o efeito do multicaminhamento, o erro do relógio do receptor GPS, a interferência da ionosfera e o erro orbital do satélite. Afirmam que o uso do DGPS como sistema de posicionamento é o mais comumente utilizado. Este sistema tem por objetivo informar o posicionamento do receptor GPS em qualquer ponto do planeta e em qualquer horário do dia. A acurácia do sistema depende de vários fatores, dentre eles: configuração do sistema GPS no momento do posicionamento; frequência do sinal GPS utilizado para o posicionamento ( $L 1, L 2$ ou $C / A$ ); configuração do receptor GPS, como taxa de aquisição, máscara de elevação, etc; interferência do multi-caminhamento no sinal GPS; método utilizado para a correção diferencial (satélite, rádio, pós-processado).

Segundo Han et al. (1994) para aumentar a acurácia do sistema, pode-se usar uma técnica de correção das posições, denominada correção diferencial. Assim, para o funcionamento do sistema de GPS diferencial ("Diferential Global Positioning System - DGPS"), um segundo receptor, denominado receptor ou estação base, deveria ser instalado em um ponto fixo e 
de coordenadas conhecidas. O erro de posicionamento pode ser estimado através da comparação entre valores calculados pelo receptor fixo de GPS e as coordenadas conhecidas do ponto. Assim, os valores das correções de posicionamento podem ser transmitidos, via rádio, para o receptor móvel, o qual fará a leitura da correção enviada pela base utilizando um rádio receptor. E o valor da posição a ser armazenado pode ser então, previamente corrigido.

Ackroyd \& Lorimer (1994) definem a correção diferencial do GPS (DGPS) como uma técnica que visa elevar o nível de desempenho, acurácia e integridade do GPS. O uso do DGPS pode reduzir consideravelmente os erros de posição.

Segundo Stafford \& Ambler (1994) a execução de algumas operações de campo, a exemplo de mapeamento da produtividade agrícola e operações de aplicação localizada de insumos, entre outras, somente podem ser realizadas com sucesso se estiverem usando um sistema adequado de posicionamento. Os autores afirmam que a posição de um determinado ponto pode ser calculado a partir das distâncias e ângulos existentes entre este ponto e outros dois ou mais pontos cujas coordenadas sejam conhecidas.

Como relatam Torres et al. (2000) o uso desta tecnologia origina uma redução de custos e aumento de produtividade para o produtor. O uso do GPS, entretanto, não se resume a determinar e gravar a posição do veículo, podendo ser utilizado como guia deste nas aplicações em faixas paralelas para a eliminação de falhas ou sobreposição entre passagens consecutivas.

De acordo com Algerbo \& Thylen (1997) a correção diferencial pode também ser obtida pelo uso de uma estação base (definidas como estação referência). A estação base é um local de coordenadas conhecidas, onde se instala um GPS e um rádio transmissor. Este tipo de correção diferencial baseia-se no fato de que o erro de posicionamento que ocorre ra estação base é simultaneamente idêntico aos erros que ocorrem em receptores de GPS, a uma certa distância da base. Entretanto, por estar num ponto de coordenadas conhecidas, a estação base identifica o erro de posicionamento a 
cada segundo e envia, por meio do rádio transmissor, o sinal de correção aos receptores ao redor da base.

Hague et al. (2000) relatam que os sistemas de posicionamento que utilizam ondas de rádio, funcionam de maneira similar aos sistemas baseados em laser. Torres de rádio são instaladas ao redor de uma determinada área que pode englobar diversas propriedades rurais. Poe meio de um rádio receptor presente no trator ou em qualquer outro veículo agrícola, determina a distância entre o veículo e cada uma das torres de rádio. Conhecendo-se essas distâncias, é possível, por triangulação, determinar a posição do veículo no campo. Segundo os autores, dependendo da altura das torres e da potência dos rádios transmissores, pode-se ter um alcance de até $50 \mathrm{~km}$.

\subsection{Mapa de produtividade}

De acordo com Han et al. (1994) a área a ser mapeada é dividida em seções menores chamadas células, sendo a produtividade medida em cada uma delas. As dimensões destas devem obedecer a determinados valores. Vários fatores físicos envolvidos no processo, como por exemplo, o tamanho da colhedora, a capacidade de leitura e aquisição dos sistemas de medição de grãos e posicionamento determinam um tamanho mínimo para as células.

Wagner \& Schrock (1989) identificaram os sistemas de medição da produtividade, de posicionamento e de aquisição de dados, como essenciais para o mapeamento de produtividade.

De acordo com Blackmore (1994) a Massey Ferguson foi a primeira companhia a produzir uma colhedora comercial para o mapeamento de produtividade dos grãos de soja e milho. Esse sistema possibilitou o monitoramento instantâneo de todas as operações realizadas pela máquina de colheita, gravando as informações em um tempo pré-determinado, incluindo a 
localização da colhedora por meio da latitude, longitude e altitude, com a respectiva produtividade da cultura.

De acordo com Han et al. (1994) o mapa de produtividade é um importante componente para a Agricultura de Precisão, pois identifica e quantifica a variabilidade espacial da produtividade das culturas e auxilia os processos de gerenciamento localizado.

Segundo Balastreire (1998) o mapeamento da produtividade de uma cultura é considerado uma das fases que apresenta a maior facilidade de execução, devido ao grande número de pesquisas já realizadas. Afirma, ainda, que a produtividade de uma cultura pode ser estimada pela pesagem direta do produto colhido e pela medição da área colhida.

Segundo Schueller (2000) o monitoramento da produtividade nas culturas de soja e milho é a tecnologia mais comercialmente popular na produção agrícola espacialmente variável e os dados históricos de produtividade se fazem necessários para se entender os efeitos do clima, em anos diferentes. Relata, ainda, que nos Estados Unidos, um dos maiores impactos da Agricultura de Precisão, foi nas vendas de produtos para a drenagem, como tubos. Mapas de produtividade de grãos e de soja mostraram a muitos fazendeiros as grandes quedas de produtividade, devido às manchas úmidas dentro dos seus campos. O potencial de lucro da drenagem foi quantificado facilmente, a partir dos mapas.

Para Queiroz et al. (2000) os mapas de produtividade da cultura podem ser utilizados como o ponto de partida, a fim de avaliar as causas da variabilidade de produtividade, bem como verificar as causas passíveis de modificações e as respostas econômicas e de impacto ambiental que o sistema de manejo, em locais específicos, pode trazer.

De acordo com Balastreire et al. (1997) um sistema de medição da produtividade é responsável por medir, direta ou indiretamente, a produção de uma cultura, em pontos cujas posições podem ser determinadas com acurácia. Quando a produtividade e a posição são determinadas ao mesmo 
tempo, o sistema de medição de produtividade é chamado de instantâneo. Os autores desenvolveram um sistema de pesagem automático para 0 mapeamento da produtividade de milho (Zea mays) com um sub-tanque adaptado dentro do tanque de grãos de uma combinada comercial.

Freitas et al. (2000) estabeleceram uma grade de 92 pontos com um espaçamento de $50 \times 50$ metros. Em cada ponto foram determinados os componentes fitotécnicos da produtividade de grãos(milho safrinha). Foram avaliados os números de vagens por planta, o número de grãos por planta e por vagem, a massa seca de 1000 grãos e a altura das plantas. Os resultados mostraram que há variabilidade espacial para todos os componentes avaliados.

De acordo com Doerge (1999) os mapas e o monitoramento da produtividade são adotados em muitos lugares nos Estados Unidos. Algumas propriedades americanas possuiam de 3 a 5 mapas de colheitas, que, de qualquer modo, somente documentam a distribuição espacial da produtividade na área, mas não permitem determinar qual o fator que causou a variação. As interpretações destes mapas aumentam as chances de entender e poder controlar os fatores de variabilidade e suas origens.

Stafford et al. (1999) em um estudo realizado em diversas fazendas na Inglaterra, utilizaram mapas de produtividade de diversas culturas para a delimitação de áreas em potenciais unidades de manejo. Coletaram por mais de três safras os dados dos monitores de colheita para a elaboração destes mapas. Analisando-os, observaram uma grande variabilidade de produtividade numa mesma safra e uma falta de consistência no padrão desta variabilidade de uma safra para outra. Para a análise posterior, estes dados foram sujeitos a técnicas de reconhecimento padrão, com o intuito de identificar sub-regiões do campo que correspondiam a um número limitado de padrões distintos de safra em safra.

Cox et al. (1999) relatam que estudos realizados na Austrália mostraram que, ao longo de cinco anos, com a introdução de técnicas da Agricultura de Precisão (mapeamento de produtividade, amostragem do solo e 
aplicação de gesso em taxas variáveis) trouxe um lucro, aproximado, de US\$ 563. ha ${ }^{-1}$ na cultura de beterraba.

Drummond et al. (1995) investigaram vários métodos de análise multivariada com dados de produtividade de duas safras, uma de milho e outra de soja, em uma área de 25 ha. Foram cruzados dados de fertilidade e espessura da camada superficial do solo. Poucos coeficientes de determinação superaram o valor de $50 \%$ e uma análise visual dos mapas de produtividade de dois anos indicou que a condição climática foi o fator que mais influenciou na produtividade.

Durrence et al. (1999) em um estudo no Estado da Geórgia, EUA, utilizaram uma colhedora de amendoim, equipada com um sistema monitoramento de colheita através de células de carga, para a elaboração de mapas de produtividade. Comparando as leituras dos dados obtidos pelo monitor de colheita com os dados obtidos por um vagão-balança, obtiveram uma diferença média entre os dois métodos de $3,1 \%$. A máxima diferença foi de $8,9 \%$, devido à interferências nos sinais de rádio do monitor.

Molin (2000) relata que a informação da colheita representa uma amostragem destrutiva e rão serve para o agricultor que queira diagnosticar algum problema e tantar saná-lo ou controlá-lo ainda durante o ciclo da cultura. A produtividade também apresenta variabilidade temporal e seu comportamento espacial, via de regra, não se repete com as diferentes culturas. Todavia, os mapas de produtividade contêm informações imprescindíveis e insubstituíveis.

Auerhammer et al. (1994) utilizaram duas colhedoras comerciais em um estudo sobre o uso de GPS no monitoramento da produtividade de trigo e aveia, na Alemanha. Os resultados da colheita obtidos para uma área de 17 ha, e células de $50 \times 50 \mathrm{~m}$, foram de 4 classes correspondentes a $4 \mathrm{t}^{-h^{-1}}{ }^{-1}$,-6 t.ha ${ }^{-1}, 6$ a 8 t.ha ${ }^{-1}$ e acima de 8 t.ha ${ }^{-1}$.

Segundo Clark (1999) o mapa de produtividade da cultura é um dos aspectos importantes da Agricultura de Precisão. A observação e análise 
dos mapas de produtividade, usualmente, conduzem ao desejo de entender os fatores que afetam a produtividade, de maneira que o gerenciamento das práticas no campo possa ser adequado para o desenvolvimento da cultura.

De acordo com Chan et al. (1999) o mapeamento da produtividade de culturas de laranja colhidas manualmente requer a conversão de dados obtidos por linha de plantio em mapas de linhas de contorno. O trabalho relata a experiência na utilização de técnicas de interpolação de krigagem e ponderação pelo inverso da distância e vários outros parâmetros em um talhão. Os erros na estimativa da produtividade obtidos pela interpolação, utilizando-se ambos os métodos citados, foram estimados em menos de $7 \%$.

Marques Junior et al. (2000) investigaram a variabilidade espacial de atributos químicos e granulometria do solo de uma lavoura de café na região de Patrocínio MG, dividida em duas superfícies geomórficas e observaram forte dependência do relevo nessas características. Embora não se tenha caracterizado o processo de definição, observaram dependência espacial da produtividade.

Balastreire et al. (2001a) e (2001b) realizaram um mapeamento da produtividade da cultura do café no município de Pinhal/SP, utilizando um sistema automático de pesagem de grãos e um DGPS, em uma área de 1,2 ha, de variedade Catuaí Amarelo, com 14 anos, em um espaçamento entrelinhas de 3,5m e na linha 1m, num solo Podzólico Amarelo; verificaram que há uma variabilidade da produtividade do café, com um mínimo de 1,4 tha ${ }^{-1}$ a um máximo de 18,4 t.ha ${ }^{-1}$, o que corresponde à variação de 12,9 vezes maior que o mínimo. O mapa de produtividade mostrou que existe uma região central do talhão onde a produtividade é bem maior que a média. A investigação das causas que levaram a essa maior produtividade poderá permitir a tomada de providências que aumentariam a produtividade das demais áreas.

Molin et al. (2002) realizaram um trabalho de mapeamento da produtividade de café e sua correlação a componentes de fertilidade do solo 
em duas áreas pilotos: a primeira ( 8,2 ha) no município de Gália $S P$, e a segunda área (5,3 ha) no município de Pompéia/SP. A colhedora foi instrumentada com um monitor de produtividade de café (SARTORI et al., 2002). Os componentes de correlação entre a produtividade e fertilidade do solo resultaram em valores baixos. As duas áreas apresentaram grande

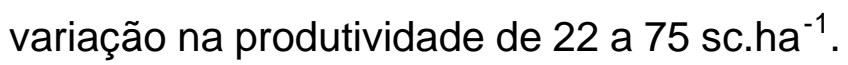

\subsection{Instrumentação}

Wild \& Rottmeier (1994) em uma pesquisa para o mapeamento da produtividade de forragens, equiparam uma enfardadora com um sistema de aquisição de dados, um receptor de GPS e vários sensores e também desenvolveram um algoritmo para analisar os dados adquiridos. A instalação do sistema e o uso do algoritmo garantiram o processo automático de aquisição de dados com alta qualidade de informação.

Reitz \& Kutzbach (1994) desenvolveram um sistema para a medição da produtividade, em que a densidade dos grãos utilizava um sistema formado por duas vigas mestras instrumentadas com "strain gage" sendo que na extremidade de uma delas existia uma massa conhecida. Na extremidade da segunda viga, uma pequena caixa com volume conhecido recebia os grãos, cuja densidade seria medida. Um sistema automático realizava a amostragem dos grãos, determinava a densidade e esvaziava a caixa, preparando-a para um novo ciclo de amostragem.

Wagner \& Schrock (1989) utilizaram um sistema de medição composto por um cilindro condutor pivotado e um sub-tanque graneleiro. Neste sistema, a massa de grãos colhida era direcionada para uma das extremidades do cilindro condutor pivotado. Por meio de um transportador helicoidal, a massa de grãos era transportada até a outra extremidade do cilindro, suspenso e conectado a uma célula de carga. A massa de grãos era, então, descarregada no interior de um sub-tanque, suspenso por três outras células de carga. $O$ 
sistema foi capaz de medir, com um erro de aproximadamente $\pm 3,0 \%$, a produtividade da cultura estudada.

Em um estudo do mapeamento de produtividade da cultura do milho, realizado por Balastreire et al. (1997), o posicionamento da colhedora foi obtido através de um GPS comercial, com correção diferencial pós-processada. A colhedora foi instrumentada com um sistema automático de pesagem desenvolvido baseando-se na pesagem direta de grãos. Construiurse um subtanque graneleiro, à capacidade máxima para $500 \mathrm{~kg}$ e fixado no interior do tanque graneleiro da colhedora, sobre 4 células de carga, com capacidade nominal de $1000 \mathrm{~kg}$ cada uma, de modo que os únicos pontos de contato entre o sub-tanque e o tanque graneleiro da colhedora eram as células de carga. $O$ sistema automático de pesagem de grãos apresentou excelente acurácia,com um erro máximo de $0.4 \mathrm{~kg}$, indicando diretamente a massa dos grãos colhidos. Este sistema, após algumas modificações, poderá ser utilizado em outras culturas.

Com relação a umidade e a densidade de grãos colhidos, Baerdemaeker et al. (1985) afirmam que os sistemas de medição de produtividade, baseados na determinação do fluxo de massa, são influenciados pela umidade e densidade dos grãos, bem como pelo fluxo médio de massa, os quais são responsáveis pela introdução de erros na determinação da produtividade. Segundo o mesmo autor o sistema volumétrico de medição de produtividade por eles desenvolvido, foi particularmente influenciado pela variação da umidade e densidade dos grãos, uma vez que o peso de um determinado material é proporcional à sua densidade afetada pela umidade dos grãos.

Sartori et al. (2002) instrumentaram uma colhedora de café com um monitor e sonar que mede o volume de grãos colhidos na unidade de tempo. De acordo com os autores, esta mensuração foi apropriada, prática, repetitiva e precisa para a elaboração do mapa de produtividade. 


\subsection{Sistema de informações geográficas-SIG}

Como relata Burrough (1986) os sistemas de informações geográficas (SIG) são um poderoso elenco de ferramentas para colecionar, armazenar, recuperar, transformar e exibir dados espaciais referenciados ao mundo real.

Segundo Coelho (1997) o SIG tem como função o armazenamento e processamento de bancos de dados, e proporcionando a análise de informações de um mesmo local.

Pedersen (1994) destacou a importância dos sistemas de informações geográficas para a Agricultura de Precisão. Segundo o autor, estes sistemas são essenciais para o processamento de dados georreferenciado e para a apresentação gráfica dos mesmos, pelo fato de permitir que diferentes parâmetros, com as mesmas posições geográficas, sejam armazenados, visualizados e processados em diferentes camadas.

De acordo com Ripple (1994) estas informações são analisadas por meio de ferramentas da geoestatística, que estabelecem critérios para a interpolação entre as células amostradas, onde são gerados os mapas de campo. São encontrados no mercado vários "softwares" que permitem o uso do SIG.

Scott \& Randy (2000) comentam que o SIG tem como essência trazer dados de diferentes fontes de um mesmo local. Estes dados integrados, desde que corretos, contribuem para a tomada de decisões. Estas, embasadas num conjunto de informações de determinado local, é um dos objetivos da Agricultura de Precisão.

Segundo Rocha \& Lamparelli (1998) os sistemas que compõem o SIG podem ser divididos em:

- Sistemas de entrada de dados: sistemas de processamento digital de imagens (PDI), digitalização de mapas, 
sistemas de posicionamento global (GPS), dados tabulares (planilhas eletrônicas) e dados estatísticos;

- $\quad$ Sistemas de armazenamento de dados: banco de dados espaciais (mapas digitais) e banco de dados de atributos (alfanuméricos);

- $\quad$ Sistemas de análises de dados: sistemas de análise geográfica (operações algébricas), sistema de análise estatística e sistema de gerenciamento de banco de dados (SGBD)

- $\quad$ Sistema de saída de dados: sistema de exibição cartográfica (saída de mapas para a tela, impressora, plotter e arquivos digitais).

Sano et al. (1998) comentam que os questionamentos dos produtores rurais sobre $\mathrm{o}$ aproveitamento de suas áreas e a estruturação das informações ambientais seriam facilitadas por intermédio de um sistema de informação geográfica (SIG), e pelo armazenamento, consulta, manipulação e análise dos dados.

\subsection{Análise Estatística}

\subsubsection{Estatística descritiva}

Uma etapa fundamental que antecede a análise geoestatística é a realização de uma criteriosa análise exploratória dos dados. Deve-se verificar a normalidade dos dados, verificar se há candidatos a dados discrepantes ("outliers") ou a necessidade da transformação dos dados para sua normalização (Isaaks \& Srivastava, 1989)

A estatística descritiva ajuda a encontrar candidatos a "outliers" nos dados obtidos. Esses candidatos a "outliers" são analisados e posteriormente excluídos ou não, dependendo do resultado da análise para não interferir no resultado final. São calculadas as medidas de peso (média, 
mediana, valor máximo e mínimo, quartis superior e inferior, amplitude e amplitude interquartil), dispersão (desvio padrão, variância e coeficiente de variação) e forma da dispersão (assimetria e curtose).

\subsubsection{Geoestatística}

De acordo com Ribeiro Júnior (1995) após um período em que a ênfase era nos delineamentos experimentais, quando, normalmente utilizam-se blocos como forma de "controlar" a variabilidade, os estudos que buscam compreender as relações de dependência espacial ganharam novo impulso com o desenvolvimento e formalização das técnicas geoestatísticas. Comenta que, estudos relacionados à mineração motivaram o desenvolvimento de ferramentas estatísticas capazes de traduzir a estrutura de variabilidade espacial de determinado atributo como, por exemplo, o teor de um minério dentro de uma região, bem como permitir interpolações que levassem a boas estimativas do teor de minério em pontos não-amostrados. Desta forma, seria possível construir mapas que exibissem a distribuição do minério na região estudada, fazer estimativas de reservas, ter parâmetros para verificar a viabilidade e orientar estratégias de prospecção.

Como relata Krige (1966) a presença de dependência espacial requer o uso de um tipo de estatística chamada geoestatística, que surgiu na África do Sul, onde o autor estava trabalhando com dados de concentração de ouro e concluiu que não conseguiria encontrar sentido nas variâncias, se não levasse em consideração a distância entre as amostras.

Segundo Lamparelli et al. (2001) a geoestatística é um conjunto de técnicas que estima valores regionalizados e espacializados de atributos ou características de determinada área a ser estudada. A ferramenta básica desta técnica é a krigagem, cujo produto é um mapa da área segundo um atributo com estimativas não viciadas e de mínima variância. $O$ autor considera a 
geoestatística bastante apropriada e, muitas vezes, fundamental para o estudo da variabilidade de determinada característica dentro de uma área específica.

Segundo Vieira (2000) é de extrema importância que o modelo estatístico adotado na análise dos dados seja validado usando os dados experimentais, para garantir assim, que as ferramentas estatísticas adequadas e corretas sejam utilizadas. Segundo o mesmo autor a geoestatística aplicada à Agricultura de Precisão tem por objetivo identificar, na aparente desordem entre as amostras, a medida de correlação espacial, realizar estimativas de valores em locais não amostrados a partir de alguns valores conhecidos na população (krigagem) e identificar inter-relações de propriedades no espaço (análise de correlação entre atributos), além de permitir estudar padrões de amostragem adequados.

Tozi (2000) estudando os Sistemas de Informação Geográfica (SIG) com aplicação na agricultura, definiu estes sistemas como um conjunto de programas, equipamentos, metodologias, dados e usuários, perfeitamente integrados, de forma a tornar possível a coleta, o armazenamento, o processamento e a análise de dados geo-referenciados, bem como a produção de informações derivadas de sua aplicação, os quais acabam interferindo de maneira positiva na administração do ciclo fenológico da cultura.

Segundo Couto \& Klamt (1999) a geoestatística, originalmente usada na indústria de mineração, tem se mostrado útil para mapear variações espaciais de propriedades de solos com os mais diversos propósitos. Os procedimentos mais comuns incluem a caracterização e o modelamento da variabilidade espacial através da estimativa dos valores nos locais não visitados, simulações espaciais, e otimização dos esquemas de amostragem (Cambardela et al. 1994). 


\subsubsection{Semivariograma}

De acordo com Vieira (1995) a análise geoestatística dos dados consiste em tentativas e erros para a elaboração do melhor modelo de um semivariograma teórico, visando a geração de um mapa que represente realmente a situação no campo pelo processo de interpolação.

O semivariograma é um gráfico que representa a semivariância dos dados ( (h)) em relação à distância correspondente que os separa (h). A estimativa da semivariância pode ser alcançada pela expressão abaixo:

$$
\gamma(h)=\frac{1}{2 n(h)} \sum_{i=1}^{n(h)}\left[z\left(x_{i}\right)-z\left(x_{i}+h\right)\right]^{2}
$$

onde:

(h) é a semivariância;

$z(x i)$ e $z(x i+h)$ são os pares de valores medidos separados por um vetor $h$;

$n(h)$ é o número de pares de valores $[z(x i)-z(x i+h)]$ separados por um vetor $h$;

z é a variável em estudo.

Para o semivariograma experimental é ajustada a curva que proporciona a máxima correlação possível com os pontos plotados. O modelo ajustado é chamado de modelo teórico do semivariograma, como ilustra a Figura 7. 


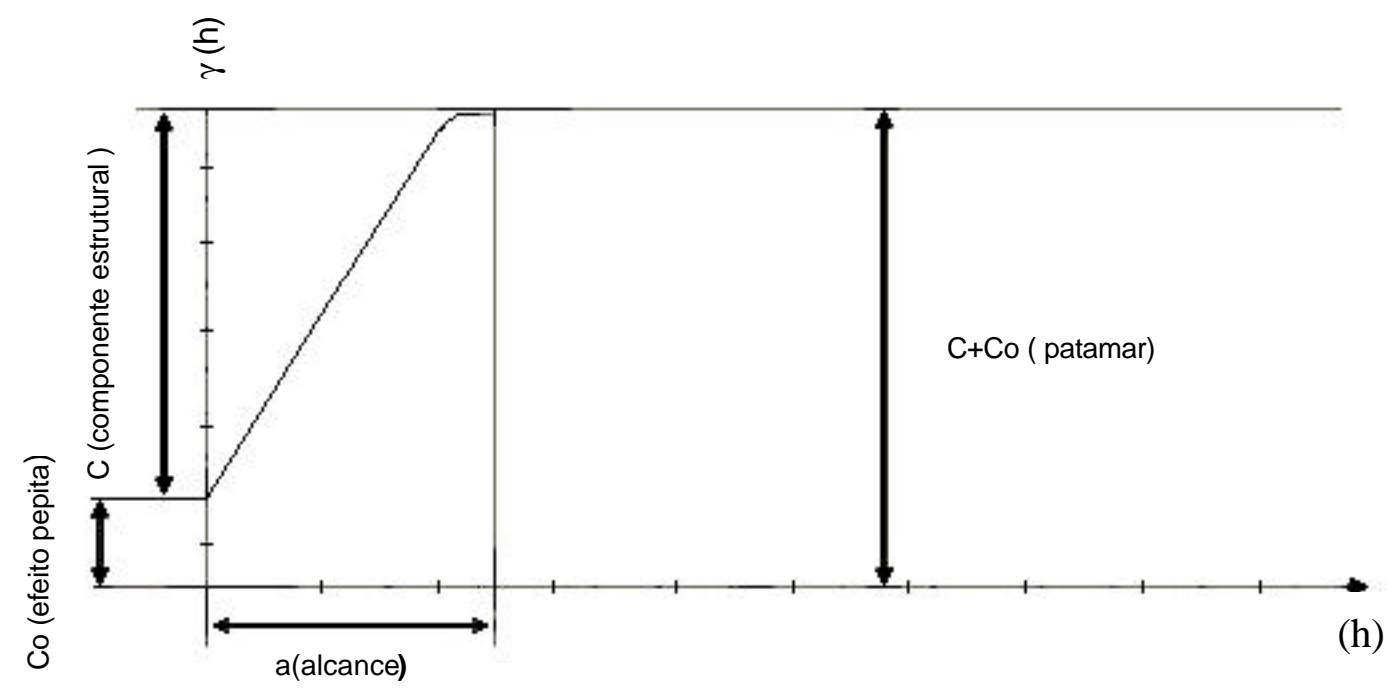

Figura 7- Semivariograma e seus componentes

De acordo com Isaaks \& Srivastava (1989) e Vieira (1995) verificaram que a semivariância decresce à medida em que a distância entre as amostras (h) decresce. Ou seja, quando as semivariâncias são menores, as semelhança entre os dados são maiores. A semivariância cresce em função de $\mathrm{h}$ até um ponto onde não se observa mais a continuidade espacial. Este ponto no eixo h é chamado de alcance do semivariograma (a) e no eixo (h) é chamado de patamar $(\mathrm{C}+\mathrm{Co})$. À medida em que $\mathrm{h}$ tende para zero, a semivariância ((h)) tende para um valor positivo chamado efeito pepita (Co). O efeito pepita engloba a variação em escala menor que a amostrada e/ou os erros ocorridos nas medições. O componente estrutural (C) é a porção da variação que é explicada pela continuidade espacial. O uso deste estimador (semivariograma) pressupõe que a propriedade atenda a uma condição de estacionaridade, segundo a qual, no mínimo, a hipótese intrínseca é atendida. Ou seja, a média da propriedade é considerada constante, pelo menos dentro de uma vizinhança compreendida pelo alcance do semivariograma e que a função de semivariância independe da posição no espaço.

De acordo com Cambardella et al. (1994) o grau de dependência espacial pode ser classificado de acordo com os seguintes critérios propostos. Semivariogramas que apresentam efeito pepita menor ou igual a $25 \%$ do 
patamar têm forte dependência espacial. A dependência é moderada quando esta relação variar de 25 a $75 \%$ e fraca quando o efeito pepita for superior a $75 \%$ do patamar.

\subsubsection{Interpolação}

Segundo Vieira (1995) a interpolação dos dados consiste em realizar inferências sobre a população; realizar inferências para os locais não amostrados a partir dos dados dos locais amostrados. O processo que faz essas inferências sobre a população é a média. A acurácia na localização das isolinhas entre dois pontos é extremamente dependente da densidade de pontos e da distância entre estes pontos. O modo para realizar inferências na localização das isolinhas é a interpolação linear. Mas esta metodologia não considera a dependência espacial entre as amostras. A forma de como os dados variam de um local para outro no campo não segue nenhuma equação matemática. Conhecido o semivariograma da variável e havendo dependência espacial entre as amostras, pode-se interpolar valores em qualquer posição no campo, sem tendência e com variância mínima, utilizando a ferramenta chamada krigagem. Esta é considerada o melhor método de interpolação linear não tendencioso, pois leva em consideração os parâmetros do semivariograma. Nenhum outro método de interpolação se baseia na variância mínima entre as amostras (o semivariograma descreve a variância mínima).

Como relatam Landim (1998) e Vieira (2000) a krigagem é o método mais estudado devido a dificuldade em sua utilização. Além disso, apresenta, entre outras vantagens, maior precisão geral e fidelidade aos dados originais.

De acordo com Almeida \& Ribeiro Junior (1996) na maioria das vezes, o interesse da análise não se limita à obtenção de um modelo de dependência espacial, desejando-se também predizer valores em pontos não amostrados. $O$ interesse pode ser em um ou mais pontos específicos da área 
em que se quer obter uma malha de pontos interpolados que permitam visualizar o comportamento da variável na região, através de um mapa de isolinhas ou desenho de superfície. Para se obter este maior detalhamento da área de estudo é necessário interpolar. Entre muitos métodos de interpolação existente, os autores citam:

- Método poligonal

- $\quad$ Triangulação

- Médias locais das amostras

- Inverso do quadrado da distância

Segundo Isaaks \& Srivastava (1989) para a realização da interpolação pela krigagem, são atribuídos pesos aos valores das amostras, dependendo da distância que separa o ponto a ser estimado e o ponto de valor conhecido. Os pesos são atribuídos de acordo com o modelo do semivariograma. Os pesos são variáveis de acordo com a variabilidade espacial dos dados. O valor do ponto desconhecido é calculado pela solução de um sistema de matrizes. 


\section{MATERIAL E MÉTODOS}

\subsection{Material}

\subsection{1 Área e cultura}

Para a realização deste trabalho foi utilizada uma área localizada na Fazenda Matinha, município de Pedregulho, região de Franca/SP, cujas coordenadas geográficas são: Latitude $20^{\circ} 18^{\prime} \mathrm{S}$; Longitude $47^{\circ} 25^{\prime} \mathrm{W}$; e uma altitude de $1094 \mathrm{~m}$, Latossolo Vermelho.

A área do projeto corresponde a 4 ha da cultura de café, cultivar Catuaí IAC 144, com 5 anos de idade, declividade de $3 \%$, altura dos pés de 1,7 m. A área foi sistematizada para a colheita mecânica com renques de $470 \mathrm{~m}$ de comprimento. Os espaçamentos utilizados foram de 3,60 m entrefileiras e 0,70 $\mathrm{m}$ na fileira de plantio, totalizando 4.000 plantas.ha $^{-1} \mathrm{~A}$ produtividade média desta lavoura, no ano de 2001, foi de 40 sacas. ha $^{-1}$ (Figura8) 


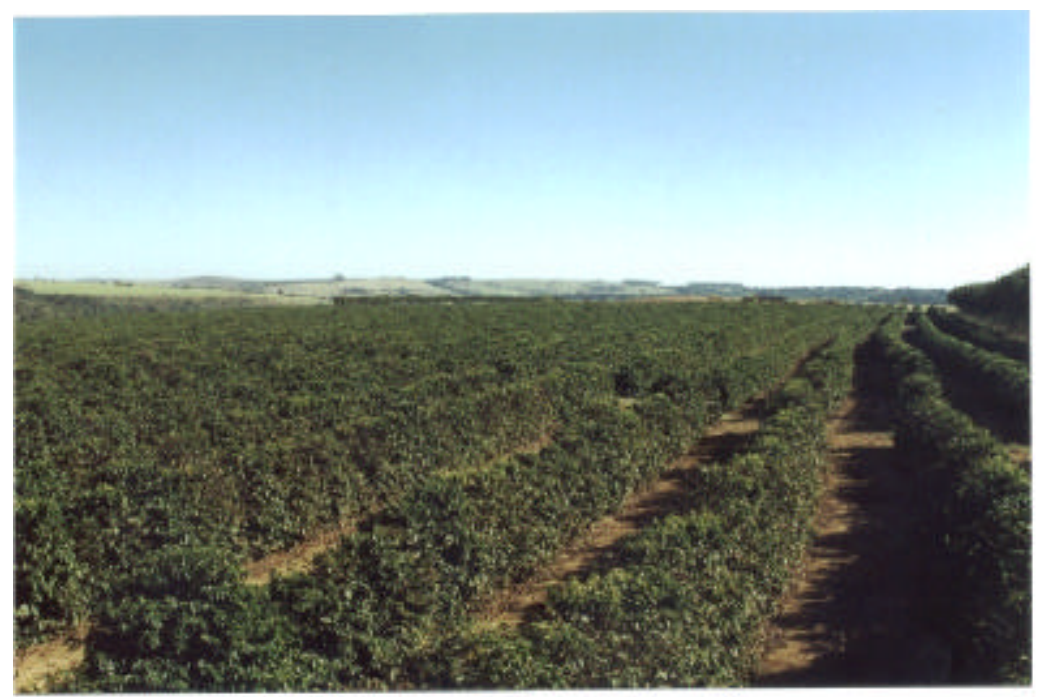

Figura 8- Vista da área experimental onde foi realizado o ensaio da colheita mecanizada do café.

\subsubsection{Colhedora}

A colheita mecanizada da área de estudo foi realizada com uma colhedora da marca Korvan,originária dos Estados unidos, modelo 9200 *, motor John Deere $\AA^{8}$ a diesel, com potência de $67,6 \mathrm{~kW}$. Sua altura varia de 3,48 $\mathrm{m}$ a $4 \mathrm{~m}$, velocidade de colheita de $0-5 \mathrm{~km} \cdot \mathrm{h}^{-1}$ e capacidade operacional de 0,7 ha. $\mathrm{h}^{-1}$. Por possuir três rodas, pode realizar curvas fechadas e manobras fáceis em carreadores de pouca largura e em locais onde a declividade do terreno dificulta a operação. O renque de café passa por dentro da máquina, entre dois eixos com hastes que vibram numa freqüência de 900 a 1000 ciclos por minuto. Essas hastes derriçam os grãos coletados em lâminas retráteis que fecham os espaços sob a saia das plantas. Esteiras internas horizontais e verticais levam o material colhido até o sistema de limpeza, onde as impurezas são separadas por ventilação. Os frutos limpos seguem, em outra esteira, para a descarga na carreta. A colhedora possui ainda uma caixa lateral basculante de reserva com capacidade de $1800 \mathrm{~kg}$ de café da roça (Figura 9).

${ }^{*} \mathrm{~A}$ citação da marca não significa o endosso do produto; destina-se apenas a perfeita caracterização deste produto. 


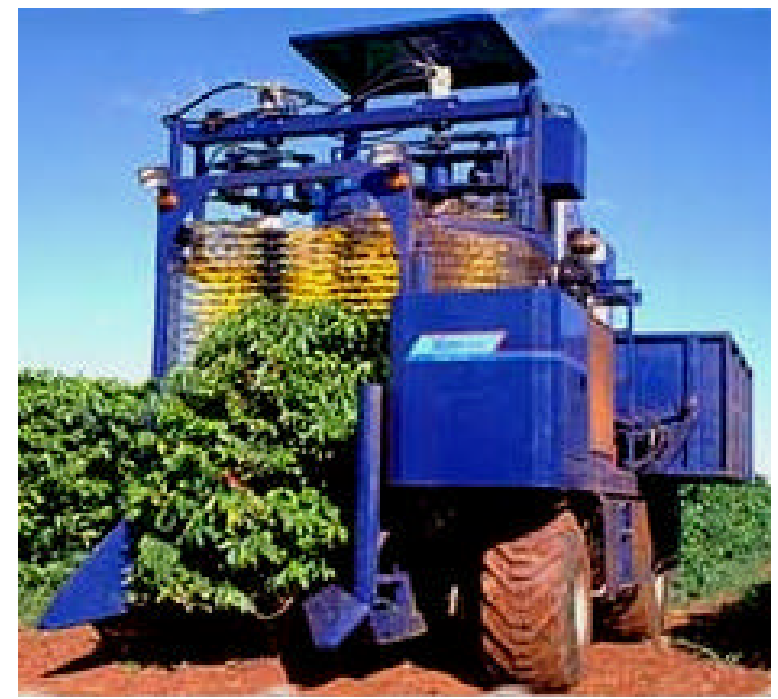

Figura 9- Vista da colhedora utilizada na operação de colheita do café.

\subsubsection{Trator e carreta}

Uma carreta SCHMBLIC (modelo dark, versão B.U), com capacidade de $3000 \mathrm{~kg}$, tracionada por um trator MF 265 cafeeiro, com potência de 47,8 kW foi utilizada para a recepção dos grãos de café (Figura 10).

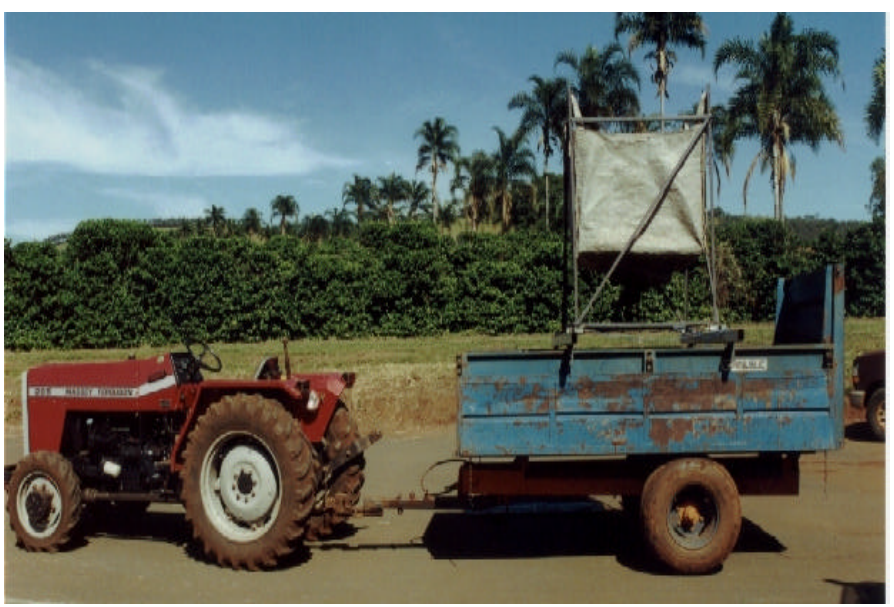

Figura 10- Carreta e trator utilizado no projeto. 


\subsubsection{Sistema automático de pesagem}

O sistema desenvolvido neste trabalho foi projetado e construído para medir diretamente e em tempo real, a massa de grãos colhidos, não exigindo, para tanto, que fossem determinadas suas umidade e densidade. Uma estrutura de ferro foi construída com cantoneiras de 50,8 mm x 5,0 mm para a fixação de 4 células de carga, de forma a ficar completamente apoiada sobre os sensores, sem nenhum outro contato. As células são da marca SODMEX, tipo NA 140, com capacidade de $9800 \mathrm{~N}$ e uma acurácia de 0,98 N, ligadas em paralela e fixadas sobre duas barras de ferro, colocadas sobre as bordas laterais da carreta para a realização da colheita. O "bigbag" foi então fixado nas hastes (ganchos) superiores da estrutura (Figura11). Para verificar a acurácia do sistema de medição foram realizados ensaios estáticos e dinâmicos; estes utilizaram 7 pesos padrões (sacos de brita) de 579 N, 549,4 N, $570 \mathrm{~N}, 608 \mathrm{~N}, 520 \mathrm{~N}, 578,8 \mathrm{~N}, 740,6 \mathrm{~N}$, sendo o sistema de medição da produtividade carregado com estes pesos, partindo-se do valor $0,0 \mathrm{~N}$ até o limite máximo de 4145,8 $\mathrm{N}$.

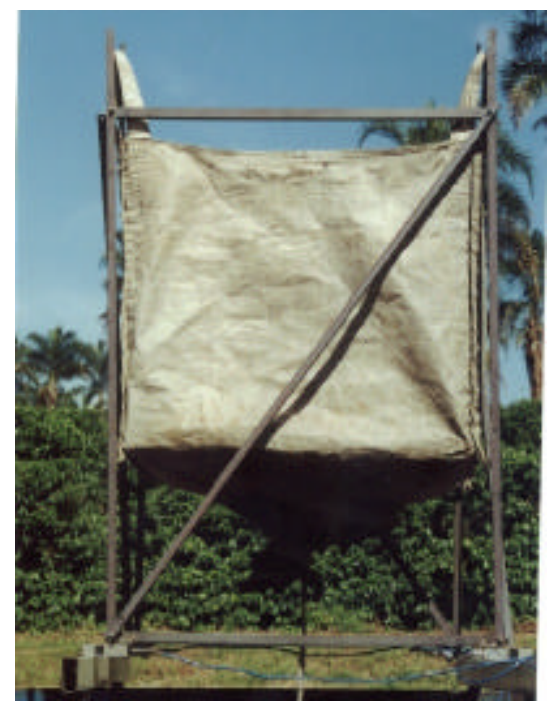

(Zoom da célula de carga)

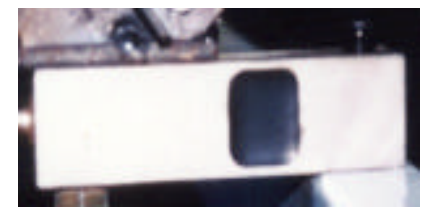

Figura 11 - Estrutura de ferro com as células de carga e "bigbag" utilizados no sistema automático de pesagem. 
A Figura 12 ilustra a descarga dos grãos de café pela colhedora no sistema de pesagem de grãos utilizando o "bigbag". Quando este atingiu sua capacidade máxima (500 kg), o sistema foi interrompido para a descarga dos grãos de café na carreta.

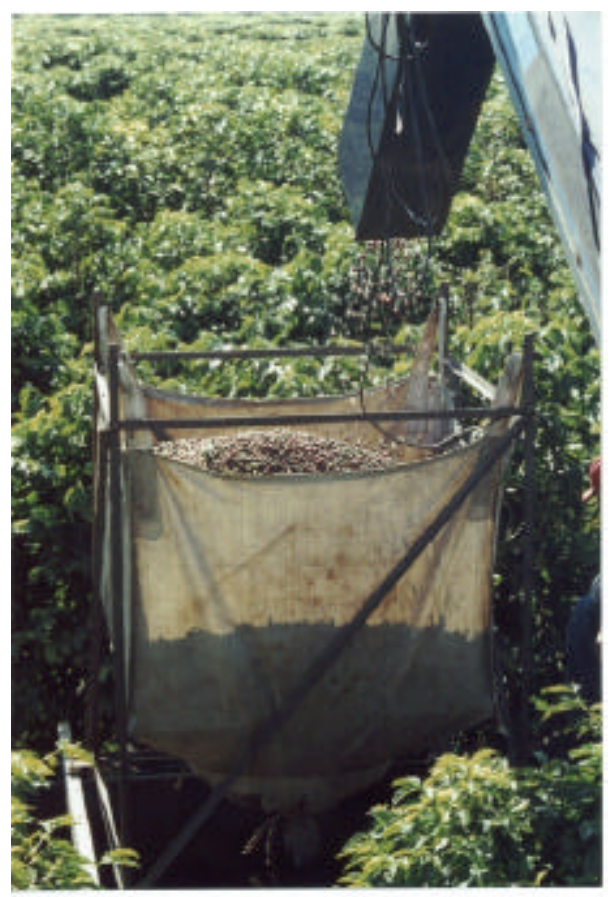

Figura 12- Operação de descarregamento dos grãos de café no "bigbag".

\subsubsection{Sistema de posicionamento global diferencial (DGPS)}

Para a localização da colhedora no campo, durante a operação de colheita, utilizourse um DGPS (Sistema de Posicionamento Global Diferencial), marca Ashtech com 10 canais e acurácia de 1 metro, composto pelos seguintes componentes ( os números à frente de cada ítem correspondem à sua posição na foto da Figura 13):

- Monitor do GPS Ashtech (1)

- Receptor de GPS (2)

- Rádio receptor Pacific Crest RFM96W, com 2 w de potência, operando na freqüência de 450-470 Mhz (3) 
- Rádio transmissor Pacific Crest RFM96S, com 35 w de potência, operando na freqüência de 450-470 Mhz (4)

- Duas antenas receptoras de sinais de GPS (5)

- Antena de rádio para transmissão do sinal de correção a partir da base(6)

- Antena de rádio para recepção do o sinal de correção (7)

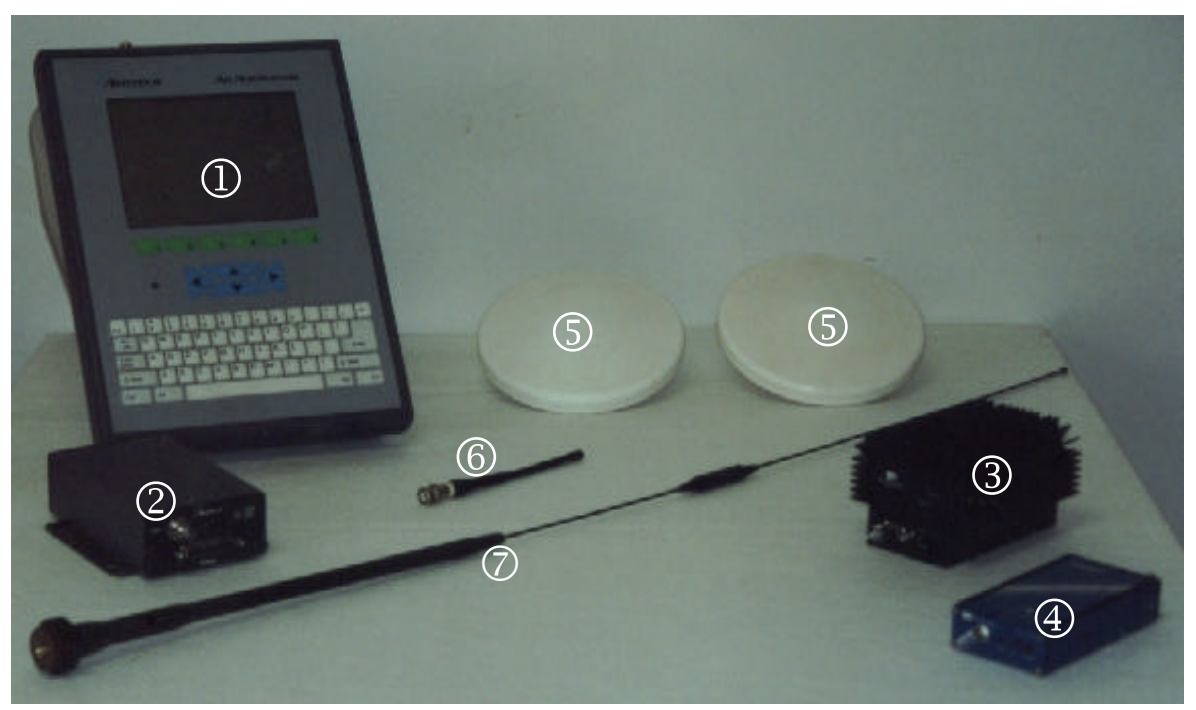

Figura 13-Constituintes do DGPS utilizado para o posicionamento da colhedora no campo.

A Figura 14 ilustra a operação de colheita, com a colhedora previamente instrumentada com o Sistema de Posicionamento Global Diferencial (DGPS) no campo experimental. 


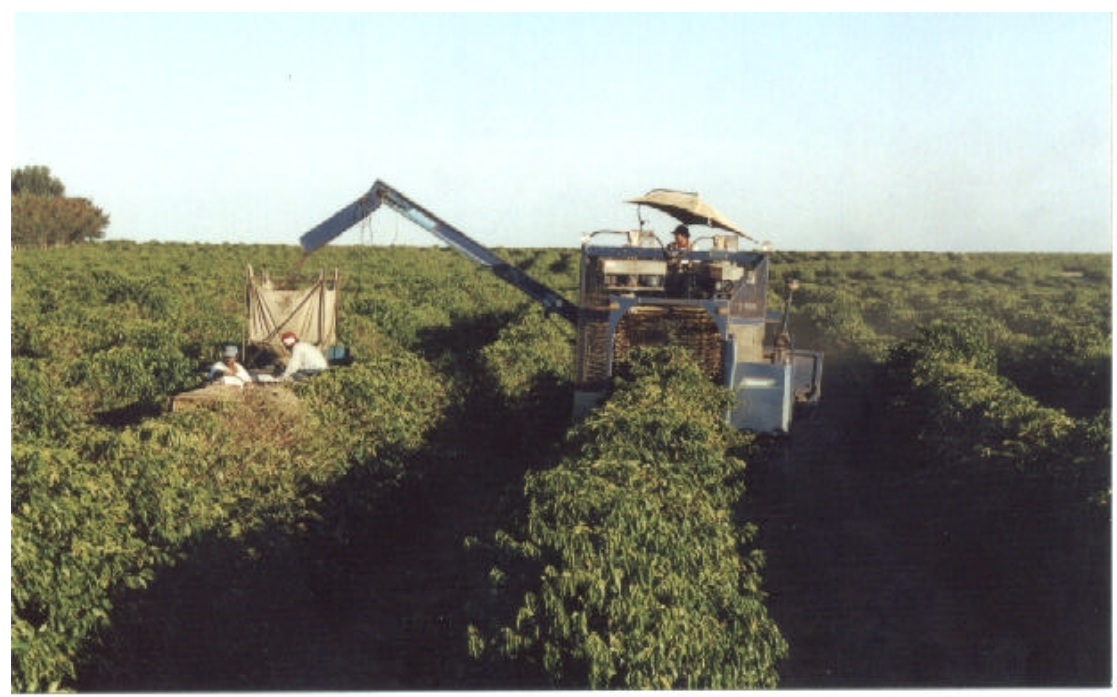

Figura 14- Operação de colheita no campo experimental.

O esquema do sistema automático de pesagem e o sistema de posicionamento global diferencial (DGPS) utilizado neste projeto estão ilustrado na Figura 15.

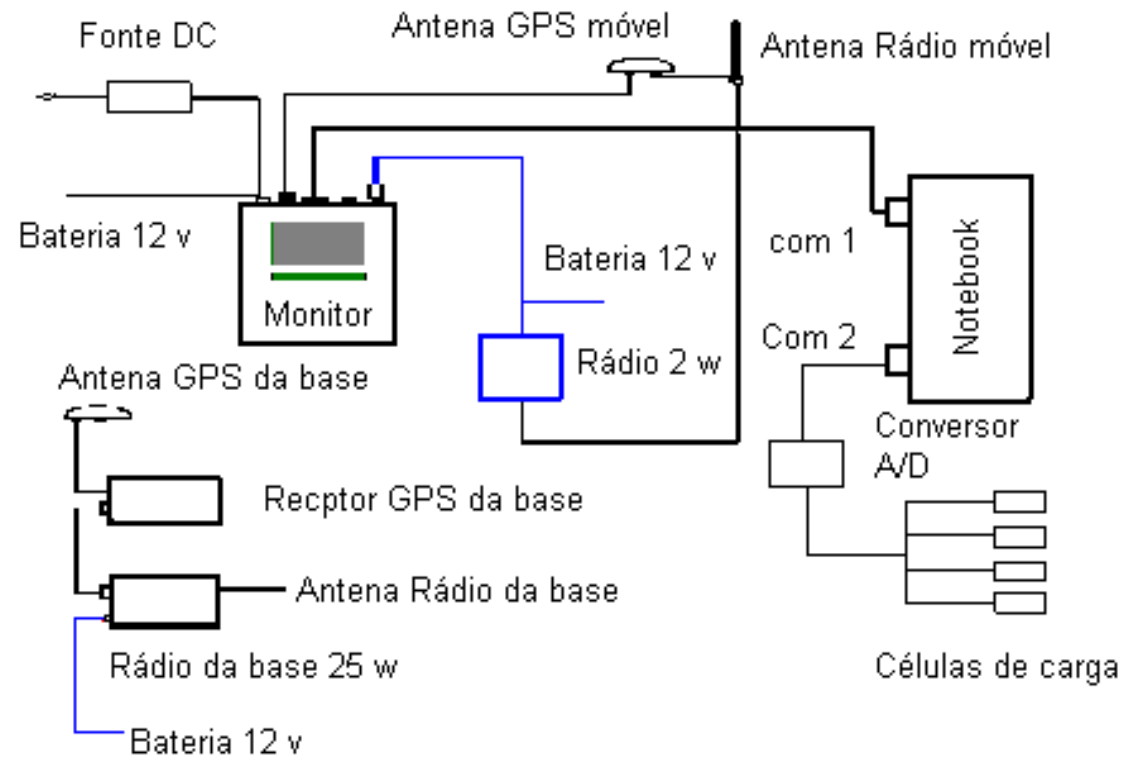

Figura 15- Diagrama do DGPS, sistema de pesagem e sistema de aquisição de dados utilizados no projeto. 
Os dados analógicos de massa provenientes das células de cargas, foram filtrados e transformados pelo Micro $\mathrm{P}$ em sinais digitais para serem lidos e gravados pelo "notebook". Este recebia também os dados de posição (latitude e longitude) provenientes do DGPS.

Para o cálculo e transmissão do sinal de correção do DGPS foi utilizada uma base estacionária no campo experimental (Figura 16).

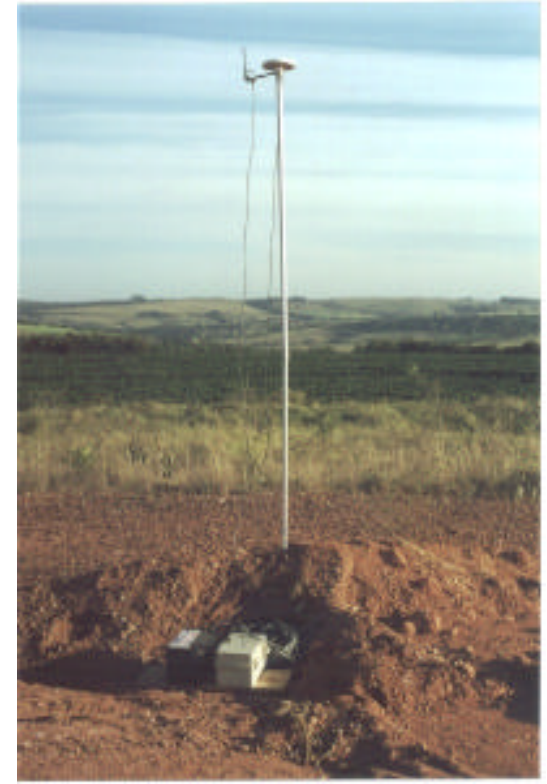

Figura16- Base estacionária com o receptor GPS fixo montada no campo.

O rádio utilizado para a transmissão do sinal de correção de posição possui uma potência de $35 \mathrm{w}$ (rádio da base) e o rádio móvel $2 \mathrm{w}$ de potência, são alimentados por uma bateria de 12 volts. A taxa de leitura da posição corrigida foi de uma a cada segundo.

\subsubsection{Sistema de aquisição de dados}

Um conversor analógico-digital (A/D) programável, da série Micro$\mathrm{P}$, de fabricação da Electro-Numerics Inc, equipado com um visor digital, filtros digitais (filtro digital 5, com uma média móvel a cada 0,6 seg) e uma saída serial padrão RS-232, foi utilizado para a conversão dos sinais analógicos 
provenientes das células de carga em valores digitais. Após a conversão dos dados, estes foram enviados ao "notebook hardbody Rocky II" dotado de um processador Cyrix 486 DX-2, com $66 \mathrm{Mhz}$ de velocidade de processamento e com 16 Mb de memória de RAM.

\subsubsection{Programas utilizados}

Para a geração e a análise dos dados do mapa de produtividade, utilizaram-se os seguintes programas:

- "SSTOOLBOX®3.2.b.0", produzido pela Sstools Dev. Group. SIG personalizado para aplicações em Agricultura de Precisão, e gerenciamento dos dados de produtividade da área

- "EXCEL for WINDOWS 2.0" produzido pela Microsoft e utilizado para processar e analisar os dados obtidos.

- "GS ${ }^{+}$Geoestatistic for the Environmental Sciences" utilizado para a análise geoestatística dos dados obtidos.

- "STATISTIC for Windows" produzido pela Statsoft, Inc. utilizado para a análise estatística descritiva dos dados obtidos. 


\subsection{Métodos}

\subsubsection{Aquisição e armazenamento dos dados de posição da colhedora e massa do material colhido}

A antena móvel do DGPS foi montada sobre a parte posterior da colhedora. Devido às características do equipamento do DGPS, os dados de posição foram coletados a uma razão exata de 1 posição por segundo. Os dados de massa foram registrados também em intervalos de 1 segundo, sendo que os valores de longitude, latitude e massa, para cada posição, foram automaticamente calculados e armazenados pelo "notebook", utilizando-se um programa escrito em linguagem Turbo $\mathrm{C}_{++}$(Anexo $\left.\mathrm{A}\right)$, que gravava os dados em formato texto.

Após o término da aquisição dos dados em campo, os mesmos foram gravados em disquete e transferidos para o computador para análise.

Após realizada a colheita mecanizada do café, foram geradas 62 planilhas em formato de texto que continham informações sobre posição (latitude e longitude) e as massa acumuladas dos grãos colhidos dentro do "bigbag". Estas planilhas foram transferidas para o programa Excel para a realização do processamento dos dados.

\subsubsection{Calibração do sistema automático de pesagem}

Os ensaios de calibrações das células de cargas utilizaram pesos padrões. A cada peso padrão inserido, foram anotados os valores de carga real 
e o valor de leitura correspondente. Após o carregamento total do sistema, este foi descarregado, também a intervalos constantes, até atingir $0,0 \mathrm{~N}$. Os dados coletados foram analisados, sendo elaborada a equação de calibração durante o carregamento e descarregamento.

O ensaio estático foi realizado com o sistema estacionado em terreno plano horizontal. O ensaio dinâmico foi realizado em área do Departamento de Engenharia Rural para avaliar o sistema em condições de operação e verificar a influência das vibrações de baixa frequência sobre este, causada pela movimentação do trator e da carreta. Para cada valor padrão de peso colocado sobre a estrutura de ferro, o trator percorreu uma distância de aproximadamente $60 \mathrm{~m}$, em plano horizontal de piso gramado irregular, durante o qual foram realizadas as aquisições dos dados de posicionamento e peso.

Após a ligação das células de carga ao conversor A/D, este foi configurado de forma a indicar a força exercida sobre os sensores. Este conversor funcionava como um filtro eletrônico, tipo passa baixo para filtrar os sinais gerados pelos sensores, minimizando os ruídos considerados de alta frequência, gerados pelos mecanismos móveis da colhedora.

$O$ conversor $A / D$ foi configurado para realizar uma filtragem digital dos dados de massa. Assim, o conversor A/D calculava um valor da média móvel dos últimos dados lidos em um determinado intervalo de tempo. Este intervalo foi fixado em 0,6 segundos. Como a cada segundo o conversor realizava 60 leituras, o valor filtrado digitalmente corresponde, numericamente, à média móvel das últimas 36 leituras de massa realizadas. 


\subsubsection{Correção de posicionamento em função do tempo de atraso no processamento do material colhido}

O tempo de processamento do material colhido, dado pela soma dos tempos necessários para a derrubada dos grãos pelas hastes da colhedora, condução do café até o sistema de esteiras, limpeza e transporte dos grãos até a carreta de a estrutura de ferro com o "bigbag", ocasionam um atraso entre os valores de peso coletados e as posições reais a eles associados. Devido a este atraso, cada valor de peso coletado corresponde à quantidade de material colhido em uma posição anterior àquele momento, proporcional ao tempo e à velocidade de deslocamento da colhedora. Para corrigir este deslocamento de posição, foi realizado um ensaio capaz de, determinar o tempo médio de processamento do material pela colhedora, em que o atraso existente entre os valores de massa e posição pudessem ser posteriormente corrigidos.

Para realizar o ensaio de determinação do tempo de retardamento dos grãos de café, a colhedora com as esteiras sem grãos, foi colocada no começo de um renque de café para iniciar a colheita. A determinação do tempo médio de retardamento, ocorreu com a máquina deslocando-se em velocidade de operação $\left(1 \mathrm{~km} \cdot \mathrm{h}^{-1}\right)$. Assim que os primeiros grãos de café eram tocados e derrubados pelas hastes da máquina, o cronômetro era disparado; quando os primeiros grãos eram descarregados dentro da carreta o cronômetro era paralisado e anotado o tempo decorrido.

Este procedimento foi realizado 10 vezes, sendo considerado como tempo de retardamento referente ao processamento, o valor da média aritmética simples dos tempos obtidos nestas repetições.

Uma vez determinado o tempo de retardamento, os dados foram corrigidos, deslocando-se cada um dos valores de massa a uma distância proporcional ao tempo médio de atraso. 


\subsubsection{Determinação do ponto representativo do centro das células}

A determinação dos pontos representativos dos centros das células foi realizada de acordo com a metodologia descrita por Balastreire et al. (1997), deslocando-se o centro da célula na direção contraria ao deslocamento da colhedora, uma distância igual ao produto da velocidade da colhedora pelo tempo de atraso determinado. A Figura 17 ilustra a posição do centro da célula. O anexo B contém uma figura que ilustra os centros de todas as células do talhão.

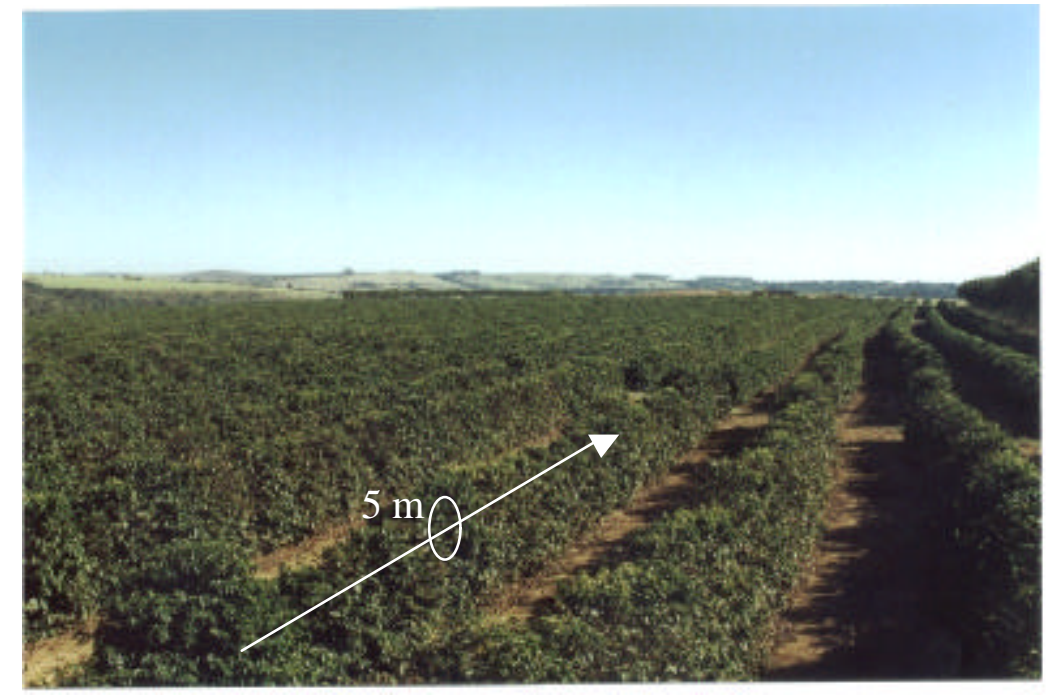

Figura 17- Determinação do ponto representativo do centro da célula.

\subsubsection{Cálculo da produtividade}

Realizada a determinação dos pontos representativos dos centros das células, os quais continham os valores de peso acumulado de grãos no interior do "bigbag", foram determinadas as produtividades individuais de cada célula.

Para a elaboração final do mapa de produtividade, as coordenadas de posição foram transformadas em UTM o que permitiu calcular 
a distância entre os centros de cada célula. A área de cada célula foi calculada multiplicando-se o comprimento dela pelo espaçamento entre renques da cultura correspondente a 3,6 metros. A produtividade foi calculada dividindo-se o peso acumulado naquela distância, pela área respectiva. O comprimento das células para o cálculo da produtividade foi de 10 metros, sendo que o valor de produtividade desta área foi representado no meio da célula, portanto a 5 metros das suas extremidades transversais. Para a correção da posição do centro de cada célula foi utilizado o tempo de atraso já descrito. A Figura ilustra a determinação do centro das células.

A produtividade foi calculada por meio da equação (2) abaixo:

$$
\text { Pr odutividade }=\left(\frac{X_{2}-X_{1}}{\left(Y_{2}-Y_{1}\right) \times E}\right) \times H
$$

Onde:

$X_{2}=$ Massa na Posição $2(\mathrm{~kg})$

$X_{1}=$ Massa na Posição $1(\mathrm{~kg})$

$Y_{2}=$ Distância acumulada da posição $2(\mathrm{~m})$

$Y_{1}=$ Distância acumulada da posição $1(\mathrm{~m})$

$E=$ Espaçamento entre linhas $(\mathrm{m})$

$$
H=1 \text { hectare }=10000\left(\mathrm{~m}^{2}\right)
$$

O quadro 2 ilustra parte de uma planilha do Excel e o cálculo da produtividade. 


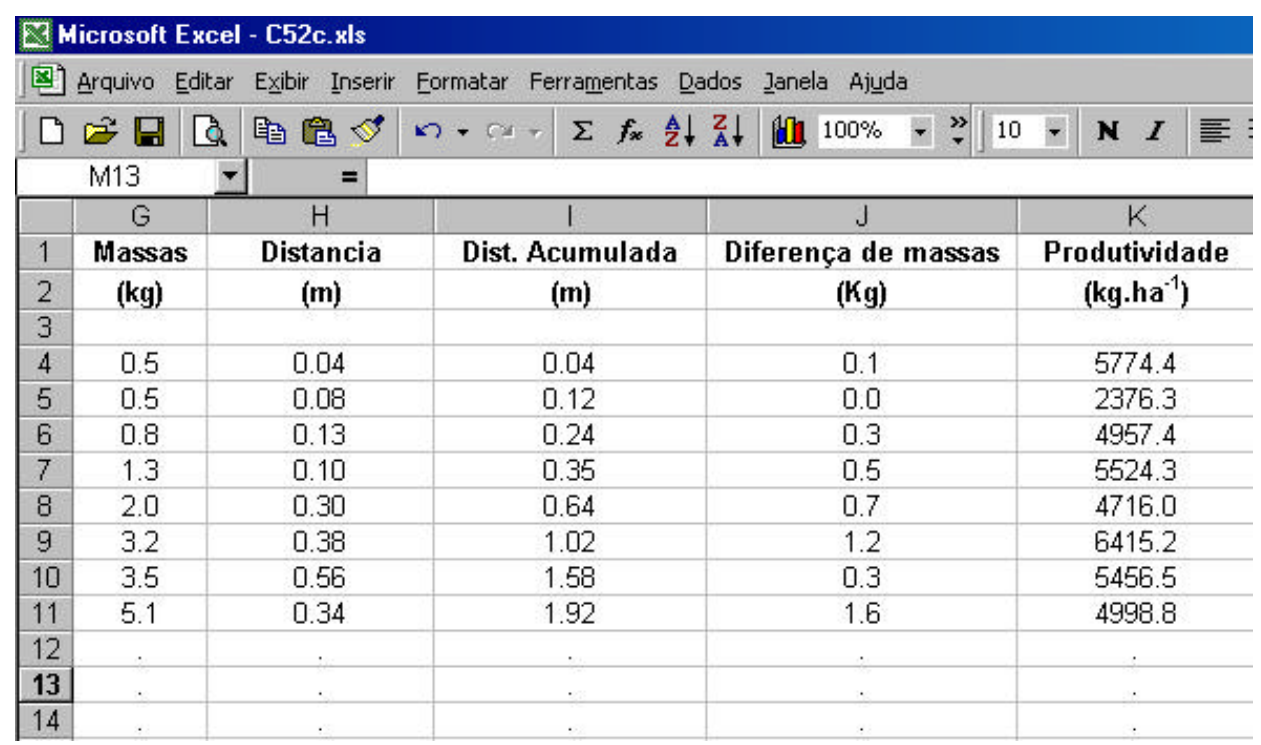

Quadro 2- Ilustração da parte de uma planilha original do Excel utilizada para o cálculo de produtividade.

A produtividade foi transformada em $\mathrm{kg} \cdot \mathrm{m}^{-1}$ linear de renque, e a partir desse valor, em $\mathrm{kg} \cdot \mathrm{ha}^{-1}$ de café recém colhido (café da roça).

\subsubsection{Análise dos dados}

\subsubsection{Análise estatística descritiva}

Fez-se uma análise estatística descritiva para a verificação do comportamento dos dados quanto às medidas estatísticas de posição e de variabilidade, bem como em relação à distribuição normal. Nestas análises, assume-se que as observações são independentes espacialmente, isto é, as variações de um lugar para outro são consideradas aleatórias, não considerando a variável posição. O objetivo foi analisar o comportamento inicial dos dados de massa.

Os dados foram analisados pelos momentos estatísticos: média, variância, desvio padrão, assimetria, curtose e coeficiente de variação. 
A variabilidade dos dados de massa dos grãos colhidos foram classificados de acordo com os critérios propostos por Warrick \& Nielsen (1980), que consideram os valores do coeficiente de variação (CV) entre 17,43 e $46,48 \%$ como de média variabilidade e os valores abaixo e acima, como de baixa e alta variabilidade, respectivamente.

O comportamento da distribuição dos dados de massa do material colhido foi verificado pelos critérios propostos por Spiegel (1985), que sugere os valores do coeficiente de assimetria (AS) e curtose (K) próximos de 0 e 3 , respectivamente, como distribuição normal dos dados. Para verificar a normalidade dos dados analisados, elaborourse um histograma no programa $\mathrm{GS}^{+}$, para análise dos valores da assimetria e curtose dos dados observados.

\subsubsection{Análise geoestatística}

$\mathrm{Na}$ análise geoestatística, o comportamento dos dados de massa do material colhido é associado às suas posições na região amostrada. Para identificar a estrutura de dependência espacial, utilizou-se a função semivariância.

A análise geoestatística dos dados consiste em tentativas e erros para a elaboração do melhor modelo de semivariograma teórico, visando a geração de um mapa que representa realmente a situação no campo, pelo processo de interpolação por krigagem.

A partir dos valores de semivariância, construiu-se 0 semivariograma experimental para o conjunto de dados de massas dos grãos do material colhido. O semivariograma foi gerado pelo programa "GS" que calculou automaticamente o semivariograma para as direções mencionadas e ajustou o modelo teórico que melhor caracterizava o fenômeno na área estudada. O modelo teórico utilizado na interpolação de valores em pontos não amostrados foi a técnica de krigagem ordinária. 


\subsubsection{Geração do mapa de produtividade}

Para cada célula criada, identificada pelas coordenadas geográficas de seu centro, foi determinada uma produtividade correspondente, formando assim, um banco de dados contendo os valores de latitude, longitude e produtividade correspondentes.

Após realizada a etapa de formação de banco de dados no programa Excel, a planilha completa, contendo todas as células do talhão georreferenciadas com as respectivas produtividades de cada ponto, foi exportada para o programa "SStolbox 3.2.0.b" utilizado para a obtenção do mapa de produtividade do café.

Pelas aplicações sucessivas da krigagem ordinária, elaborou-se o mapa de isolinhas da produtividade da área experimental, utilizando-se o programa de SIG "SStoolsbox 3.2.0.b". 


\section{RESULTADOS E DISCUSSÃO}

\subsection{Sistema de medição da produtividade-calibração estática}

A curva de calibração estática das células de carga pode ser vista na Figura 18.

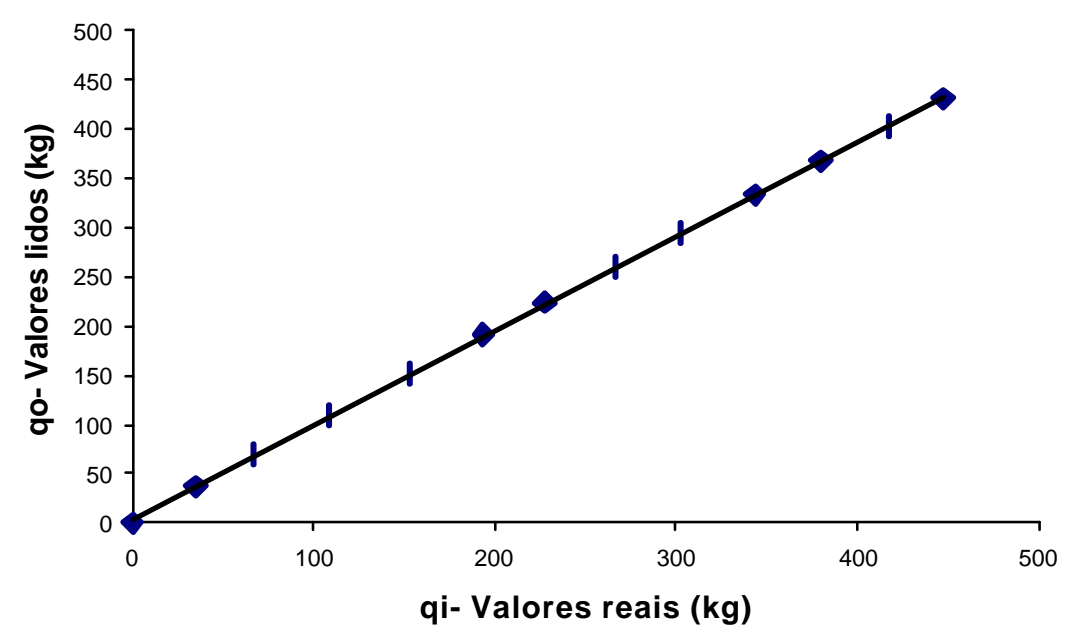

Figura 18- Curva de calibração obtida para o sistema de medição da produtividade, durante o carregamento e descarregamento.

A equação de calibração obtida no ensaio estático do sistema automático de pesagem pode ser expressa em massa:

$y=1,0218 x-2,284$

onde:

$\mathrm{y}=$ massa indicada pelo sistema de medição $(\mathrm{kg})$

$\mathrm{x}=$ valor real da massa no interior do "bigbag" $(\mathrm{kg})$ 
Os desvios padrões para saída e entrada foram calculados de acordo com a metodologia descrita por Doebelin (1966) equações (4 e 5):

$$
\begin{aligned}
& \mathrm{s}_{\mathrm{qo}}=\sqrt{\frac{1}{N} \sum\left(m q_{i}+b-q_{0}\right)^{2}} \\
& \mathrm{~s}_{\mathrm{qi}}=\sqrt{\frac{\left(S q_{0}\right)^{2}}{m^{2}}}
\end{aligned}
$$

Assim, os limites estatísticos de erro $\left(\mathrm{s}_{\mathrm{qo}}\right)$ obtidos para o sistema em carregamento e descarregamento, ainda em condições estáticas, foram de $1,283 \mathrm{~kg}\left(\mathrm{~s}_{\mathrm{qo}}\right)$ e $1,255 \mathrm{~kg}\left(\mathrm{~s}_{\mathrm{qi}}\right)$.

Assumindo-se a massa real para o fundo de escala de $422,6 \mathrm{~kg}$, a massa real medida pelas células de carga foi de $433 \mathrm{~kg}$. A mesma massa calculada pela equação da reta foi de $428,8 \mathrm{~kg}$. A diferença entre os dois valores, denominado erro sistemático para o fundo de escala foi de $6,2 \mathrm{~kg}$, ou $1,4 \%$ de erro.

Para se determinar o erro total do sistema, somourse o erro sistemático com o erro ao acaso (3sqi) e obteve-se um erro total de $-6,2 \mathrm{~kg} \pm$ $3,76 \mathrm{~kg}$.

O sistema de medição de pesagem direta dos grãos utilizado neste trabalho, dispensa a necessidade de se determinar a umidade ou a densidade do material colhido, como nos casos citados anteriormente.

\subsection{Sistema de medição da produtividade - calibração dinâmica}

Os resultados da análise estatística do ensaio da calibração dinâmica para os dados coletados com a filtragem digital está ilustrado na Tabela 3. 
Tabela 3. Resultados da análise estatística do ensaio da calibração dinâmica para os dados coletados.

\begin{tabular}{lccc}
\hline \multicolumn{1}{c}{ Parâmetros } & \multicolumn{3}{c}{ Massa (kg) } \\
\multicolumn{1}{c}{ Estatísticos utilizados } & $\mathbf{7 5}$ & $\mathbf{2 3 5}$ & $\mathbf{4 2 3}$ \\
\hline Desvio médio & 0,38 & 1,11 & 4,71 \\
Desvio padrão & 0,53 & 1,36 & 5,51 \\
\hline
\end{tabular}

Para o ensaio dinâmico realizado, o máximo desvio médio obtido foi de $4,71 \mathrm{~kg}$, para um total de $423 \mathrm{~kg}$ no interior do "bigbag", o que representou uma variação percentual de $1,11 \%$ em relação a massa real existente.

\subsection{Correção de posicionamento em função do tempo de atraso}

O resultado do ensaio de correção de posicionamento em função do tempo de atraso do material colhido está ilustrado na Tabela 4.

Tabela 4. Dados do ensaio para a determinação do tempo de atraso dos grãos colhidos.

\begin{tabular}{cc}
\hline № Repetições & Tempo decorrido (s) \\
\hline 1 & 19,56 \\
2 & 21,17 \\
3 & 18,94 \\
4 & 20,54 \\
5 & 19,06 \\
6 & 22,10 \\
7 & 19,17 \\
8 & 20,75 \\
9 & 19,86 \\
10 & 20,13 \\
\hline Média & 20,11 \\
\hline
\end{tabular}


A média aritmética das repetições do tempo de atraso do material colhoido foi de 20,11 segundos. Para o cálculo da correção de posicionamento dos centros das células utilizourse a equação 6 :

$$
\mathrm{Dc}=\Delta \mathrm{t} * \mathrm{~V}
$$

Onde:

$\mathrm{Dc}=$ Deslocamento do centro da célula $(\mathrm{m})$

$\mathrm{V}=$ Velocidade da colhedora na operação de colheita $\left(\mathrm{m} \cdot \mathrm{s}^{-1}\right)$

$\Delta t=$ Tempo de atraso dos grãos colhidos (s)

Sendo a velocidade da colhedora $1 \mathrm{~km} \cdot \mathrm{h}^{-1}$ e o tempo médio de atraso no processamento do material colhido de 20,11 segundos, assim, os posicionamentos dos centros das células foram deslocadas 5,6 metros.

\subsection{Aquisição dos dados de posição e massa}

A Tabela 5 mostra parte de uma planilha com os dados de posição e massa geradas pelo sistema (Tabela 5).

Tabela 5. Parte de uma planilha do excel gerada pelo sistema de aquisição de posição e massa.

\begin{tabular}{ccccccc}
\hline \multicolumn{3}{c}{ Latitude } & \multicolumn{3}{c}{ Longitude } & Massa \\
$\left({ }^{\circ}\right)$ & $\left({ }^{\prime}\right)$ & $(")$ & $\left({ }^{\circ}\right)$ & $\left({ }^{\prime}\right)$ & $(")$ & $(\mathrm{kg})$ \\
\hline 20 & 19 & 6,91 & 47 & 25 & 26,16 & 1,6 \\
20 & 19 & 6,89 & 47 & 25 & 26,17 & 3,1 \\
20 & 19 & 6,86 & 47 & 25 & 26,19 & 3,4 \\
20 & 19 & 6,84 & 47 & 25 & 26,2 & 4,1 \\
20 & 19 & 6,83 & 47 & 25 & 26,21 & 6,1 \\
20 & 19 & 6,82 & 47 & 25 & 26,22 & 6,2 \\
20 & 19 & 6,81 & 47 & 25 & 26,23 & 7,4 \\
20 & 19 & 6,8 & 47 & 25 & 26,24 & 8,3 \\
. &. &. &. &. &. &. \\
. &. &. &. &. &. &. \\
. &. &. &. &. &. &. \\
\hline
\end{tabular}




\subsection{Massa acumulada de material colhido}

A quantidade de grãos colhidos e armazenados temporariamente no "bigbag" durante o deslocamento da colhedora está ilustrado na Figura 19. A linha contínua representa os valores de massa coletados ponto a ponto em uma passada da máquina no renque de café.

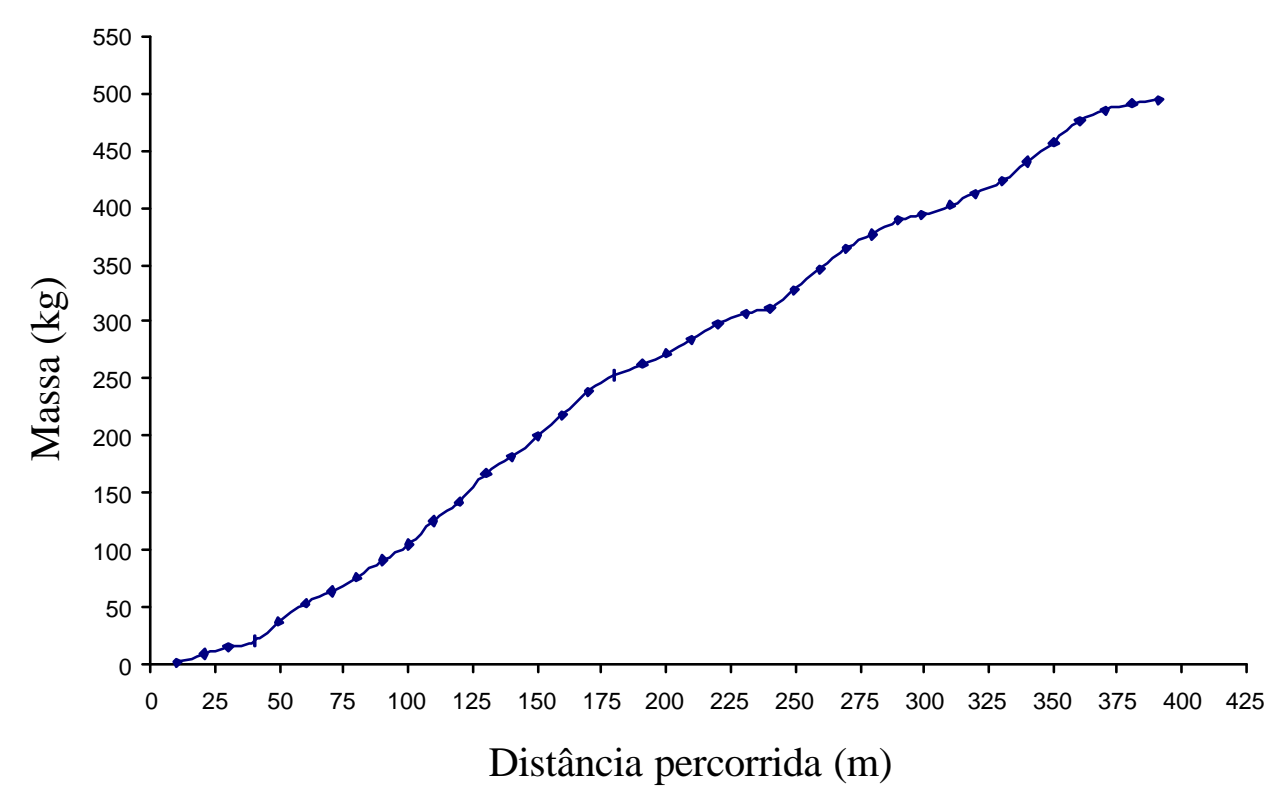

Figura 19- Representação da massa acumulada no interior do "bigbag" em função da distância percorrida pela colhedora. Massa média obtida em intervalos constantes de 10 metros, para uma passada.

Observa-se pelo gráfico da Figura 19 que o filtro utilizado para minimizar os erros momentâneos de leitura de massa, causados pelas vibrações a que a colhedora estava sujeita na operação foi eficaz, não se verificando picos de massa entre as leituras. 


\subsection{Análise estatística descritiva dos dados}

A Figura 20 mostra a distribuição de frequência dos valores de massa, comparada com a curva de distribuição normal esperada.

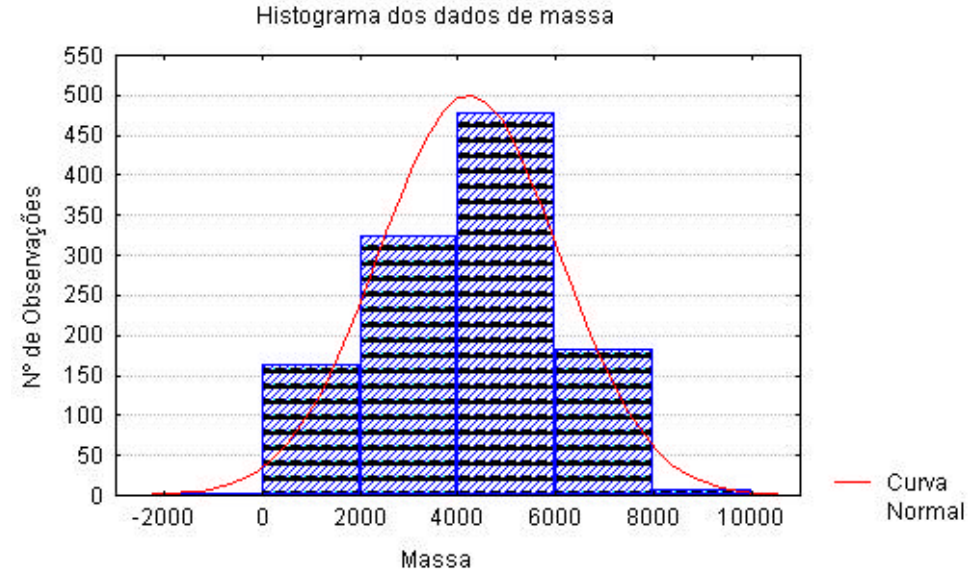

Figura 20- Histograma dos dados de massa

Os valores de massa apresentaram distribuição regular em torno da mediana (4427.3), com discreto aumento no comprimento do segmento entre o quartil superior (5563.8) e o valor máximo (8762.6). Isso ocorre devido a presença de dados com valores superiores a média.

Os valores estatísticos dos dados de massa, obtidos na área experimental, estão representados na Tabela 6.

Tabela 6. Valores estatísticos dos dados de massa colhida da área experimental.

\begin{tabular}{|c|c|c|c|c|c|c|c|c|c|}
\hline Parâmetros & № pontos & $\begin{array}{c}\text { Média } \\
(\mathrm{kg})\end{array}$ & $\begin{array}{l}\mathrm{DP} \\
(\mathrm{kg})\end{array}$ & Variância & $\begin{array}{c}\text { Mínimo } \\
(\mathrm{kg})\end{array}$ & $\begin{array}{c}\text { Máximo } \\
(\mathrm{kg})\end{array}$ & As & $\mathrm{K}$ & $\begin{array}{l}\text { CV } \\
(\%)\end{array}$ \\
\hline Massa & 1155 & 4225,9 & 184,7 & 3395900 & 26,2 & 8782,6 & $-0,37$ & $-0,41$ & 41 \\
\hline
\end{tabular}


De acordo com Warrick \& Nielsen (1980) o valor do coeficiente de variação (CV) de $41 \%$ demonstra que os dados de massa do material colhido possuem uma variabilidade média, os valores dos coeficientes de assimetria e curtose próximos de 0 sugerem uma distribuição normal para os dados de massa, como mostra a Figura 20.

\subsection{Análise geoestatística dos dados de massa}

O semivariograma experimental com o respectivo modelo ajustado para os dados de massa da área pode ser visualizado na Figura 21.

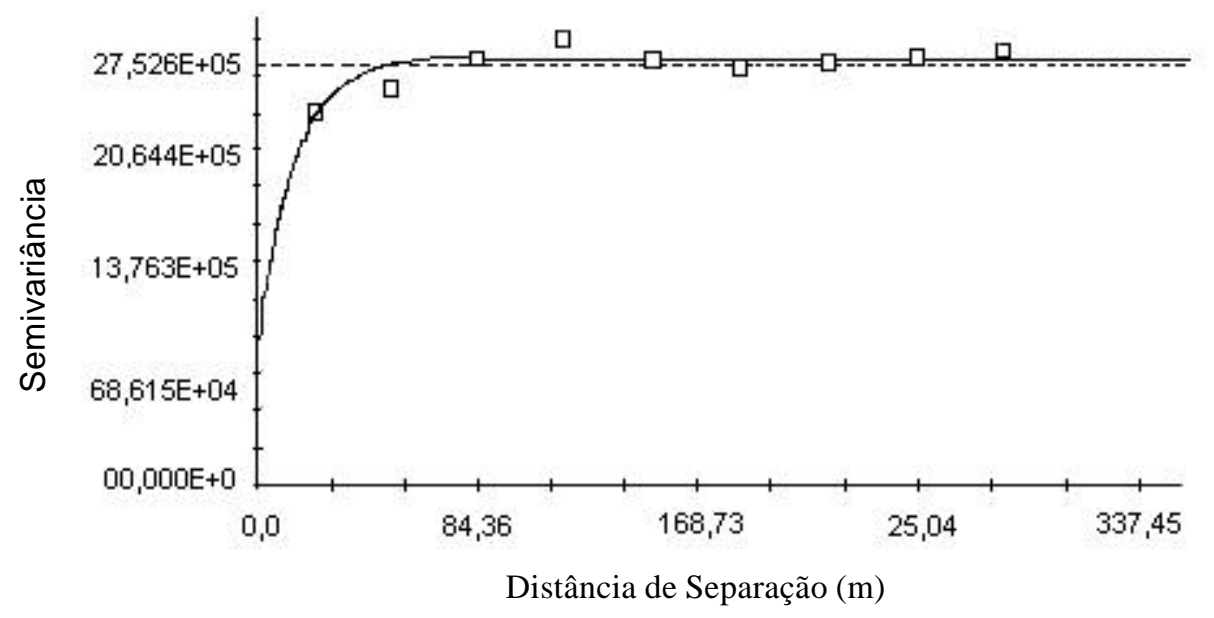

Figura 21 - Semivariograma experimental, mostrando o modelo ajustado para os dados de massa.

A tabela 7 mostra os parâmetros do modelo do semivariograma ajustado e o efeito pepita, patamar e alcance.

Tabela 7. Parâmetros do modelo do semivariograma ajustado.

\begin{tabular}{|c|c|c|c|c|c|}
\hline Modelo & ${ }^{1} \mathrm{Co}$ & ${ }^{2} \mathrm{Co}+\mathrm{C}$ & ${ }^{3} \mathrm{Ao}(\mathrm{m})$ & ${ }^{4} R^{2}$ & ${ }^{5}[\mathrm{Co} / \mathrm{Co}+\mathrm{C}] \cdot 100$ \\
\hline esférico & 1026000 & 3372000 & 27,2 & 0,992 & 30,42 \\
\hline
\end{tabular}


Para todos os modelos utilizados na elaboração do semivariograma, o que melhor representou os dados de massa foi o modelo esférico.

De acordo com resultados apresentados por Cambardella (1994) os dados de produtividade apresentaram uma dependência espacial moderada, uma vez que o coeficiente do efeito pepita $(\mathrm{Co} / \mathrm{Co}+\mathrm{C})$ foi de $30,42 \%$.

\subsection{Mapeamento da produtividade da cultura de café}

O formato inicial de uma planilha com dados de posição (latitude e longitude) e a produtividade ( $\left.\mathrm{kg} \cdot \mathrm{ha}^{-1}\right)$ está ilustrado na Tabela 8.

Tabela 8. Exemplos de dados de posição e produtividade de algumas células, para obtenção de um mapa de produtividade.

\begin{tabular}{ccc}
\hline Latitude & Longitude & Produtividade $\left(\mathrm{kg} \cdot \mathrm{ha}^{-1}\right)$ \\
\hline$-20,3180218$ & $-47,4234838$ & 3915,83 \\
$-20,3179320$ & $-47,4235050$ & 5945,24 \\
$-20,3178555$ & $-47,4235227$ & 6154,52 \\
$-20,3177790$ & $-47,4235452$ & 1860,17 \\
$-20,3177133$ & $-47,4235693$ & 5285,37 \\
$-20,3176263$ & $-47,4235965$ & 5915,47 \\
$-20,3175428$ & $-47,4235280$ & 3571,90 \\
$\cdot$ & $\cdot$ & $\cdot$ \\
$\cdot$ & $\cdot$ & $\cdot$ \\
\hline
\end{tabular}

O sistema de posicionamento (DGPS) utilizado no estudo apresentou resultados adequados para a localização da colhedora no talhão da cultura estudada e para o levantamento da área em questão. Os dados obtidos das localizações e massa, após terem os seus posicionamentos corrigidos e 
analisados pelo programa de SIG utilizado, resultaram no mapa de isolinhas da produtividade da cultura de café, ilustrado na Figura 22.

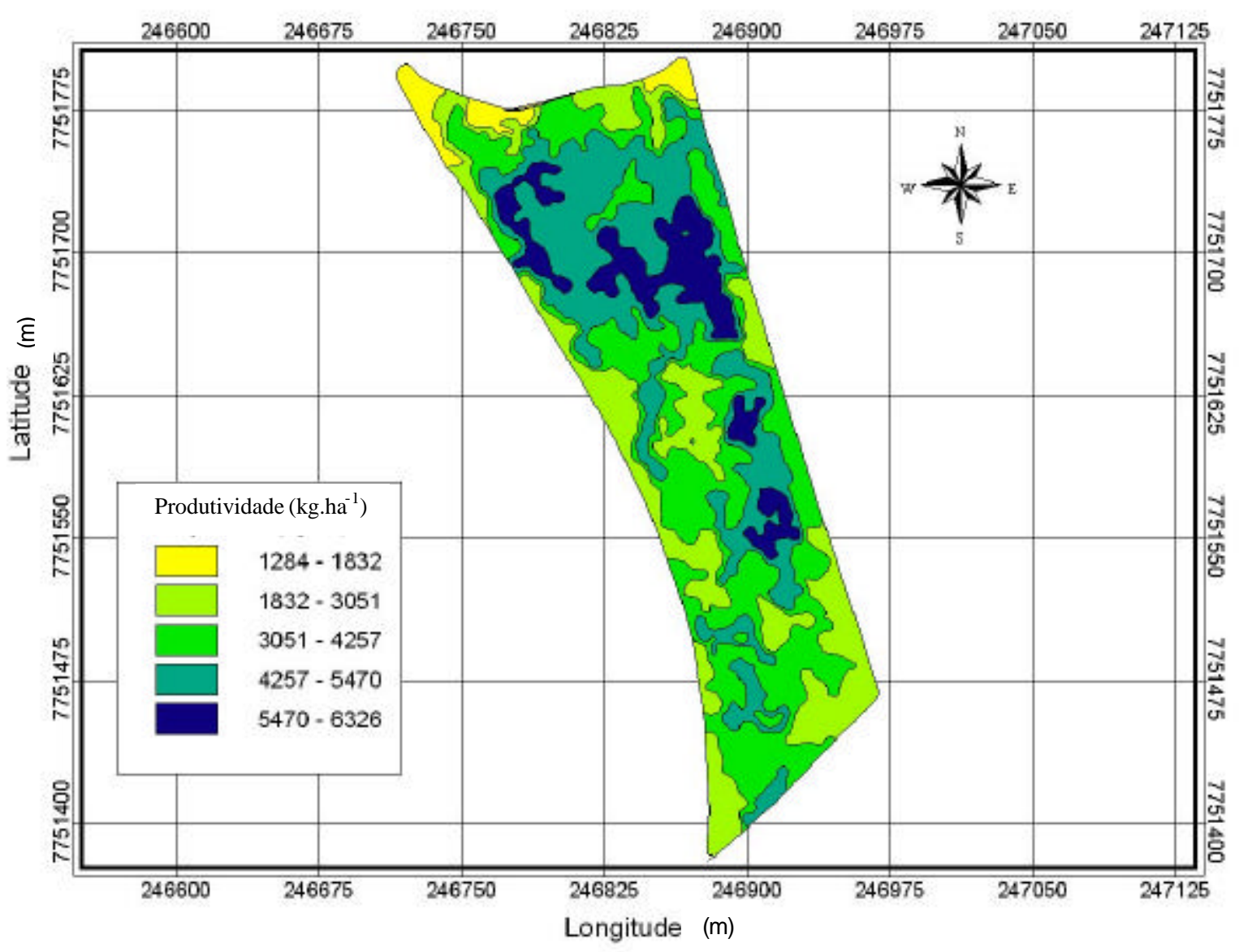

Figura22 - Mapa de isolinhas de produtividade da cultura de café.

Após a interpolação por krigagem, a obtenção do mapa de isolinhas evidenciou significativas variações na produtividade do café que resultaram em valores de $1284 \mathrm{~kg} \cdot \mathrm{ha}^{-1}$ até $6326 \mathrm{~kg}$.ha ${ }^{-1}$ de café recém colhido (café da roça).

O mapa de isolinhas evidencia 4 regiões de maior produtividade do talhão, e mostra as regiões de menor produtividade.

A diferença de produtividade nas diversas áreas do talhão sugere que elas podem se caracterizar em zonas de manejo, que deveriam ser 
gerenciadas de forma localizada, o que indica o potencial de utilização dos conceitos de Agricultura de Precisão para a cultura de café.

Há que se considerar que o cafeeiro é uma planta que apresenta oscilações de produtividade, denominado ciclo bienal. Assim, as regiões de menor produtividade neste ano, podem ter sido regiões de maior produtividade anteriormente.

Esta peculiaridade da cultura implica na necessidade de avaliações sucessivas (pelo menos 2 anos no mesmo local) para que o mapa de produtividade possa ser utilizado como ferramenta para o manejo da cultura. 


\section{CONCLUSÕES}

O mapa de produtividade mostrou que existem 4 áreas do talhão onde a produtividade é bem maior que a média, o que indica o potencial de uso dos conceitos de Agricultura de Precisão, para o gerenciamento localizado na cultura de café. A investigação das causas que levaram à variabilidade da produtividade poderá levar a identificação de providências que permitam aumentar a produtividade das demais áreas, com o seu conseqüente benefício.

O sistema automático de medição da produtividade desenvolvido

apresentourse adequado, podendo ser utilizado para a quantificação da variabilidade espacial da produtividade da cultura do café, por meio da medição direta da massa acumulada de grãos colhidos. Este sistema apresenta um potencial para ser utilizado em escala comercial.

O DGPS utilizado apresentou acurácia adequada para a elaboração do mapeamento de produtividade do café.

Os programas utilizados para a elaboração dos mapas de produtividade mostraram-se adequados para a aquisição e processamento dos dados, bem como para a elaboração dos mapas de produtividades. 


\subsection{Sugestões para estudos futuros}

Adaptação do sistema automático de pesagem no chassi da colhedora.

Amostragem do material colhido para cada célula, para o cálculo das porcentagens de café em coco, cereja e verde.

Mapeamento das porcentagens acima descritas. 
ANEXOS 


\section{ANEXO A}

Fluxograma do programa Turbo $\mathrm{C}^{++}$utilizado no ensaio.

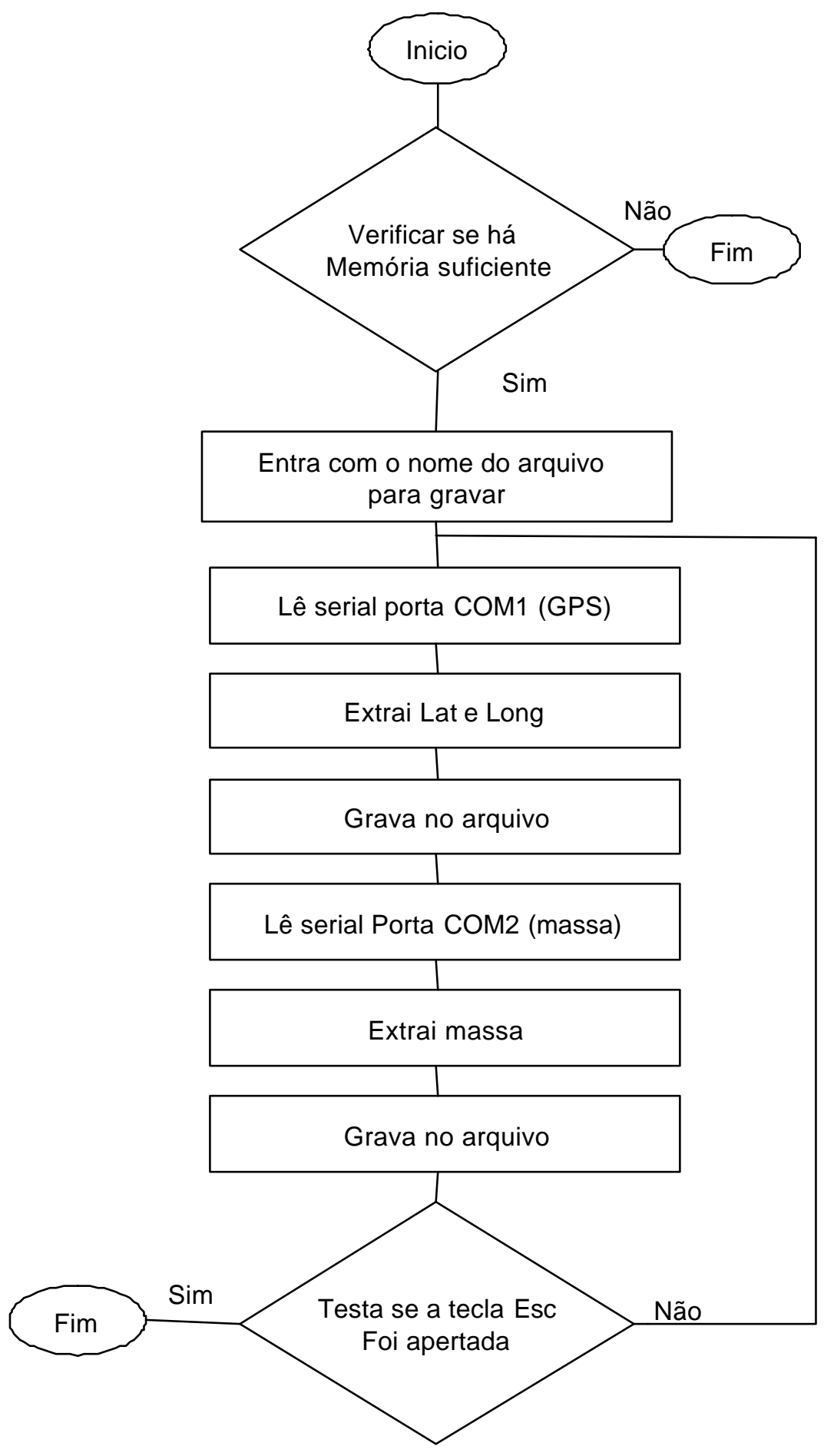




\section{ANEXO B}

Determinações dos pontos representativos dos centros das células.

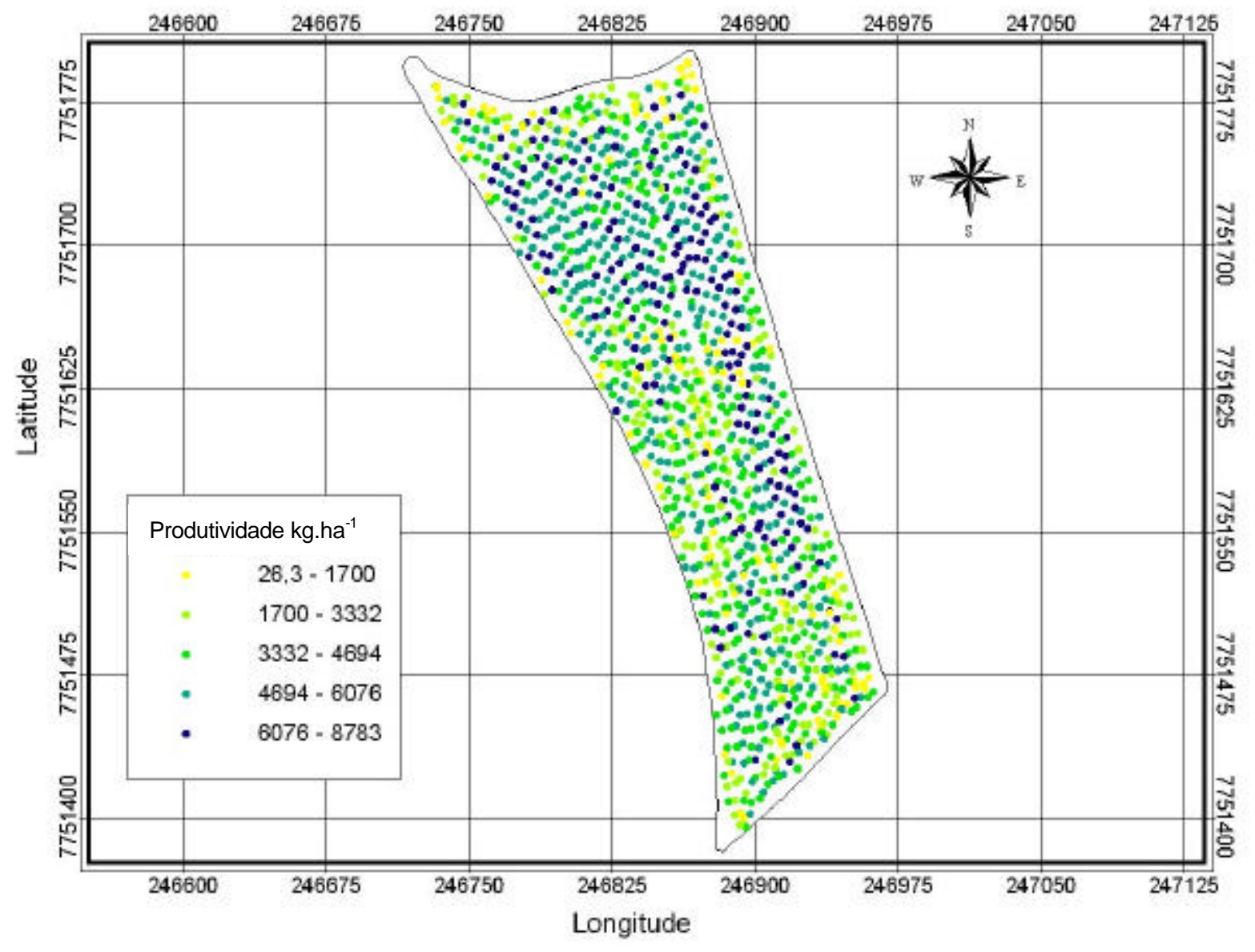




\section{REFERÊNCIAS BIBLIOGRÁFICAS}

ACKROYD, N.; LORIMER, R. Global navigation: a GPS user's guide. 2.ed. London: Lloyd's of London Press, 1994. 196p.

FNP CONSULTORIA \& COMÉRCIO. Agrianual 2001: anuário da agricultura brasileira. São Paulo, 2001 p.221-243: Café.

FNP CONSULTORIA \& COMÉRCIO. Agrianual 2002: anuário da agricultura brasileira. São Paulo, 2002. p.208-244: Café:

ALGERBO, P.A.; THYLEN, L. Coast guard beacon system. In EUROPEAN CONFERENCE ON PRECISION AGRICULTURE '97, 1., Warwick, 1997. Proceeding. London:BIOS Scientific, 1997. p.545-550.

ALMEIDA, C.F.P. de.; RIBEIRO JÚNIOR, P.J. Estimativa da distribuição espacial de retenção de água em um solo utilizando krigagem indicatriz. Curitiba: Universidade Federal do Paraná, Departamento de Estatística, 1996. 37p. (Relatório Técnico do Laboratório de Estatística).

AUERNHAMMER, H.; DEMMEL, M.; MUHR, T.; ROTTMEIER, J.; WILD, K. GPS for yield mapping on combines. Computers and Electronics in Agriculture, v.11, p.54-68, 1994. 
BAERDEMAEKER, J.; DELCROIX, R.; LINDEMANS, P. Monitoring the graw flow on combines. In: AGRI-MATION ${ }^{\mathrm{TM}} 1$ CONFERENCE \& EXPOSITION, Chicago,1985. Proceedings. St. Joseph: ASAE, 1985. p.329-338.

BALASTREIRE, L.A. Agricultura de precisão. Piracicaba, 1998. 68 p

BALASTREIRE, L. A.; ELIAS, I. A.;AMARAL, J. R. Agricultura de precisão: mapeamento da produtividade da cultura de milho. Engenharia Rural,v.8, p.97-111,1997.

BALASTREIRE, L. A.; AMARAL, J.R.; LEAL, J.C.G.; BAIO, F.H.R. Agricultura de precisão: Mapeamento da produtividade de uma cultura de café. http://www.cagri.usp.br/ leia/resucafe.htm. (11 Maio, 2001a).

BALASTREIRE, L. A.; AMARAL, J.R.; LEAL, J.C.G.; BAIO, F.H.R. Agricultura de precisão: mapeamento da produtividade de uma cultura de café (compact disc). In: CONGRESSO BRASILEIRO DE ENGENHARIA AGRíCOLA,30., Foz do Iguaçu, 2001. Jaboticabal:SBEA, 2001 b.

BAIO, F.H.R.; ÂNGULO FILHO, R.; VETTORAZZI, C.A.; RAFFO, J.G.G.; ELIAS, A.I. Estudo da exatidão de um GPS operando em duas taxas de aquisição de dados. In: CONGRESSO BRASILEIRO DE ENGENHARIA AGRÍCOLA, 27., Poços de Caldas, 1998. Anais. Jaboticabal: SBEA, 1998, p.347-349.

BLACKMORE, S. Precision farm: an indroduction. Outlook on Agriculture, v. 23, n.4, p.275-280,1994. 
BLACKMORE, B.S.; LARSCHEID, G. Strategies for managing variability, In: EUROPEAN CONFERENCE ON PRECISION AGRICULTURE 1997, 1., Warwick, 1997. Proceedings. London:BIOS Scientific, 1997. p.851-859.

BLITZKOW, D. NAVSTAR/GPS: Um desafio tornado realidade . In: SIMPÓSIO BRASILEIRO DE GEOPROCESSAMENTO, 3., São Paulo, 1995. Anais. São Paulo:USP, 1995. p.429-462.

BURROUGH, P.A. Principles of geographical information systems: methods and requirements for land use planning. Oxford: Clarendon Press, 1986. 120p.

CAMBARDELLA, C.A.; MOORMAN, T.B.; NOVAK, J.M.;PARKIN, T.B.; KARLEN, D.L.; TURCO, R.F.; KONOPKA, A.E. Field-scale variability of soil properties in central lowa soils. Soil Scince Society of America Journal. v.58, n.5, p.1501-1511, 1994.

CHAN, C. W.; SCHUELLER, J.K.; WHITNEY, J.D.; WHEATON, T.A. Interpolation errors in citrus yield mapping. In: ASAE FLORIDA SECTION ANNUAL CONFERENCE, Key Largo, 1999. Proceedings. Key Largo, ASA, CSSA, SSSA, 1999. p.243-258.

CLARK, R.L. Evaluation of the potential to develop soil strength maps using a cone penetrometer. St. Joseph: ASAE, 1999.

CLARK, R.L.; MCGUCKIN, R.L. Variable rate application technology: na overview. In: INTERNATIONAL CONFERENCE ON PRECISION FARMING, 3., Minneapolis, 1996. Procedings. Madision: ASA, CSSA,SSSA, 1996. p.855-862. 
COELHO, J.L. Agricultura de precisão: tendências e desafios. Notesalq., v.5, n.10, p.4-5, abr 1997.

COLVIN, T.S.; JAYNES, D.D.B.;KARLEN, D.L.; LAIRD, D.A.; AMBUEL, J.R. Six year yield variability within a central lowa field. In: INTERNATIONAL CONFERENCE OF THE AMERICAN SOCIETY OF AGRONOMY, Minneapolis, 1996. Proceeding. Minneapolis:ASA, CSSA, SSSA, 1996. p.863-870.

COUTO, E.G.; KLAMT, E. Variabilidade espacial de micronutrientes em solo sob pivô central no sul do Estado de Mato Grosso. Pesquisa Agropecuária Brasileira, v.34, p.2321-2329, 1999.

COX, G.; HARRIS, H.; COX, D. Application of precision agriculture to sugar cane. In: INTERNATIONAL CONFERENCE ON PRECISION AGRICULTURE, 4.,Madison, 1999. Proccedings. Madison: ASA,CSSA,SSSA, 1999. p.753-763.

DANNA, P. Global positioning system overview. the geographer's craft project, Department of Geografhy, University of Texas at Austin. URL:www.utexas.edu/depts/grg/gcraft/notes/gps/gps.html). (13 abril 2000)

DOEBELIN, E.O. Measurement systems application and design, Washington: Mac Graw Hill Book. 1966. 439 p.

DOERGE, T. A. Journal of Production Agriculture. Johnston, IA 50131 USA. 1999 
DRUMMOND, S.T.; SUDDUTH, K.A.; BIRREL, S.J. Analysis and correlation methods for spacial data. S.t. Joseph: ASAE, 1995. 22 p.

DURRENCE, J.S.; PERRY, C.D.;VELLIDIS, G.; THOMAS, D.L.; KVIEN, C.K. Mapping peanut yield with an experimental load cel yield monitoring system. In: INTERNATIONAL CONFERENCE ON PRECISION AGRICULTURE, 4., Madison, 1999. Proceedings. Madison: ASA,CSSA,SSSA, 1999. p.11311141.

EVANS, L.T.; WARLAN, I. F.; FISHER, R. A. Wheat. In: EVANS, L. T. Crop physiology. London: Cambridge University. Press, 1975. p.49-101.

FERGUSON, R.B.; GOTWAY, C. A.; HERBET, G. W.; et al. Soil sampling for site-specific nitrogen management. In : INTERNATIONAL CONFERENCE ON PRECISION AGRICULTURE. 3., Mineapolis, 1996. Procedings. Minneapolis: ASA,CSSA,SSSA Press, 1996. p.3-12.

FOUNTAS, S. Market research on the views and perceptions of farmers about the role of crop management with precision farming. Silsoe, 1998. 84p. Thesis (M.Sc.) - Cranfield University.

FREITAS, J.G.; MOLIN, J.P.; MARIA, I.C.; CANTARELLA, H.; DUARTE, A P. Componente da produtividade de soja, visando obter parâmetros para a agricultura de precisão. In: BALASTREIRE, L. A (Ed.). O Estado-da-arte da agricultura de precisão no Brasil. Piracicaba, 2000. p 144.

GOERING, C.E. How much and where. Agricultural Engineering, v.73,n.4,p.13-15, July, 1992. 
GOERING,C.E.; HAN,S. A field information system for SSCM. Warrendale: SAE International,1993. (SAE Technical Paper Series,932422)

HAGUE, T.; MARCHANT, J.A.; TILLET, N.D. Ground based sensing systems for autonomous agricultural vehicles. Computers and Electronics in Agriculture, v.25, p.11-18, 2000.

HAN, S. HUMMEL, J.W. GOERING, C. E. CAHN, M.D. Cell size for sitespecific crop management. Transactions of the ASAE, v.37, n.1, p.19-26, Jan/Fev. 1994.

HOLLANDS, K. R. Relationship of nitrogen and topography control crop consulting. In: INTERNATIONAL CONFERENCE ON PRECISION AGRICULTURE. 3., Mineapolis, 1996. Proceedings. Minneapolis: ASA,CSSA,SSSA Press, 1996. p.3-12.

ISAAKS, E. H.; SRIVASTAVA, R. M. An introducion to applied geostatistics. New York: Oxford University Press, 1989. 561p.

KASHIMA, T. Colheita mecanizada do café: equipamentos, desempenho e custo a nível de propriedade. In: CONGRESSO BRASILEIRO DE PESQUISA CAFEEIRAS, 12. Caxambu, 1985. Anais p.58-61.

KRIGE, D.C. Two-dimensional weighted moving average trend surface for oreevaluation. Jounal of the South African Institute of Mining and Metallurgy, v.66. p.13-38, 1966.

KRÜGER, G.; SPRINGER, R.; LECHNER, W. Global navigation satelite systems (GNSS). Computers and Eletronics in Agriculture, v.11, p.3-21, 1994. 
LAMPARELLI, A.C.; ROCHA, J.V.; BORGHI, R. Geoprocessamento e agricultura de precisão: fundamentos e aplicações. Guaíba: Agropecuária, 2001. $118 \mathrm{p}$.

LANDIM, P.M. B. Análise estatística de dados geológicos. São Paulo: Fundação Editora da Unesp, 1998. 226p.

LANGE, A.F. On datums and geoids. Gis World, v.9, n.10, p.62. 1996.

MARINO, L.K. Café Oferta maior do que o consumo ainda dura. In: FNP CONSULTORIA \& COMÉRCIO. AGRIANUAL 2002: anuário da agricultura brasileira. São Paulo, 2002. p.208-209.

MARQUES JUNIOR, J.; SANCHESZ, R.B.; PEREIRA, G.T.; CORÁ, J.E. Variabilidade espacial de propriedades químicas e físicas de latossolos em áreas de cerrado sob cultivo de café, em Patrocínio, MG. In: BALASTREIRE, L. A (Ed.). O Estado-da-arte da agricultura de precisão no Brasil. Piracicaba, 2000. p.105-112.

MOLIN, J.P. Geração e interpretação de mapas de produtividade para a agricultura de precisão. In: BORÉM, A.B.; GIÚDICE, M.P.; QUEIROZ, D.M.; MANTOVANI, E.C.; FERREIRA, LR.; VALLE, F.X.R.; GOMIDE, R.T. Agricultura de Precisão. Viçosa:UFV, 2000. p.237-258.

MOLIN, J.P.; RIBEIRO FILHO, A.C.; TORRES, F.P.;SHIRAISI, L.E.; SARTORI, S.; SARRIÉS, G.A. Mapeamento da produtividade de café e sua correlação com componentes de fertilidade do solo em duas áreas pilotos. In: BALASTREIRE, L. A. Avanços na Agricultura de Precisão no Brasil no período de 1999-2001. Piracicaba, 2002. p.58-65. 
PEDERSEN, H.H. Site-specific farming in Denmark- research and development of decision support. In: INTERNATIONAL CONFERENCE ON COMPUTERS IN AGRICULTURE, 5., Orlando, 1994. Computers in agriculture: proceedings. ST. Joseph: ASAE, 1994. p.587-591.

PINO, F. A. A cultura do café no estado de São Paulo, 1995-96. Agricultura em São Paulo, v.46, n.2, p.106-167, 1999.

QUEIROZ, D.M de. DIAS, G.P.MANTOVANI, E.C. Agricultura de precisão na produção de grãos. In: BORÉM, A.B.; GIÚDICE, M.P.; QUEIROZ, D.M.; MANTOVANI, E.C.; FERREIRA, LR.; VALLE, F.X.R.; GOMIDE, R.T. Agricultura de Precisão. Viçosa:UFV, 2000. p.1-42.

REITZ, P.; KUTZBACH, H.D. Data acquisition for yield mapping with combine harvesters. In : INTERNATIONAL CONFERENCE OF COMPUTERS IN AGRICULTURE, 5., Orlando,1994. Proceedings, St. Joseph: ASAE, 1994. p 42-47.

RIBEIRO JÚNIOR, P. J. Métodos geoestatísticos no estudo da variabilidade espacial de parâmetros do solo. Piracicaba, 1995. 99p. Dissertação (Mestrado)- Escola Superior de Agricultura "Luiz de Queiroz", Universidade de São Paulo.

RIPPLE, W. J. The GIS applications book: examples in natural resources. Bethesda: American Society for Photogrammetry and Remote Sensing, 1994, 380p.

ROCHA, J. V.; LAMPARELLI, R. A. Geoprocessamento In: CONGRESSO BRASILEIRO DE ENGENHARIA AGRÍCOLA, 27., Poços de Caldas, 1998. Anais. Viçosa: SBEA, 1998. v.1, p.1-28. 
ROSA, M.A.; BEDUSCHI, L.C.; RÍPOLI, T.C.C.; NOGUEIRA, M.C.S. Análise dos custos operacionais de seis sistemas de colheita de café (Coffea arábica L.). CONGRESSO BRASILEIRO DE ENGENHARIA AGRÍCOLA, 20., Londrina, 1991. Resumos. Londrina: SBEA, 1991. p.1387.

SANO, E.E.; ASSAD, E. D.; MOREIRA, L.; MACEDO, J. Estruturação de dados geoambientais no contexto de fazenda experimental. In: ASSAD, E. D.; SANO, E. E. (Ed.) Sistema de informações geográficas. 2.ed. Brasília: Embrapa, Serviço de Produção de Informação, 1998. cap.6, 434p.

SARTORI, S.; FAVA, J.F.M.; DOMINGUES, E.L.; RIBEIRO FILHO, A.C.; SHIRAISI, L.E. Mapping the spatial variability of coffee yield mechanical harvester. In: WORD CONGRESS OF COMPUTERS IN AGRICULTURE AND NATURAL RESOURCES, Iguaçu Falls, 2002. Proceedings. Madison: ASA,CSSA,SSSA, 2002. p.196-205.

SEARCY, S.W. Enginneering systems for site-specific manegement: opportunities and limitations. In: INTERNATIONAL MANAGEMENT FOR AGRICULTURAL SYSTEMS, 1., Madison, 1995. Proccedings. Madison: ASA,CSSA,SSSA, 1995. p.603-611.

SCHUELLER, J.K. O Estado-da-arte da agricultura de precisão nos Estados Unidos. In: BALASTREIRE, L. A (Ed.). O Estado-da-arte da agricultura de precisão no Brasil. Piracicaba, 2000. p.8-15.

SCOTT, S.; RANDY, T. Predicting grain yield variability using infrared images. In: INTERNATIONAL CONFERENCE ON PRECISION AGRICULTURE. 6., Minnesota, 2000 Proceedings. Minnesota: ASA,CSSA,SSSA Press, 2000. p.208-215. 
SPIEGEL, M.R. Estatística. 2.ed. São Paulo: McGraw-hill, 1985. 454p.

STAFFORD, J.V.; AMBLER, B. In-field location using GPS for spatially variable field operations. Computers and Electronics in Agriculture, v.11, p.23-36, 1994.

STAFFORD, J.V.; LARK, R. M.; BOLAM, H.C. Using yield maps to recognize fields into potencial management unit. In: INTERNATIONAL CONFERENCE ON PRECISION AGRICULTURE, 4., Madison, 1999. Proceedings. Madison: ASA,CSSA,SSSA, 1999. v.2, p.1285-1286.

STEVEN, M.D; MILLAR, C. Satelite monitoring for precion farm decision support. In: INTERNATIONAL CONFERENCE ON PRECISION AGRICULTURE, 4., Madison, 1999. Proceedings. Madison: ASA,CSSA,SSSA, 1999. p. 225-237.

STRAUSS, C.; CUGNASCA, C.E.; SARAIVA, A.M.; PAZ, S.M. The iso11783 standart and its use in precision agriculture equipment. In: INTERNATIONAL CONFERENCE ON PRECISION AGRICULTURE, 4., Minneapolis, 1998. Procedings. Minnessota: ASA,CSSA,SSSA, 1998. v.2, p.1253-1261.

TAGLIALEGNA, G. H. F.; SILVEIRA, M.C.S. Colheita mecanizada para reduzir custos. In: FNP CONSULTORIA \& COMÉRCIO. AGRIANUAL 2002: anuário da agricultura brasileira. São Paulo, 2000. p.228.

TORRES, F.P.; RIBEIRO FILHO, A.C.; BAIO, F.H.R. Comparação da utilização da barra de luz na Agricultura de Precisão em relação ao marcador de espuma. In: BORÉM, A.B.; GIÚDICE, M.P.; QUEIROZ, D.M.; MANTOVANI, E.C.; FERREIRA, LR.; VALLE, F.X.R.; GOMIDE, R.T. Agricultura de precisão. Viçosa:UFV, 2000. p.357-364. 
TOZI, F.A. Sistemas de informação geográfica na agricultura. In BALASTREIRE, L. A (Ed.). O Estado-da-arte da agricultura de precisão no Brasil. Piracicaba, 2000. p.187-192.

VEGRO, C. L. R. Café: realidade e perspectivas. São Paulo, 1997. 79 p. (Coleção Cadeias de Produção da Agricultura, 2)

VIEIRA, S. R. Geoestatística em estudos de variabilidade espacial do solo. In: NOVAIS, R. F.; ALVAREZ, V.H.; SCHAEFER, C. E. G. R. (Ed) Tópicos em ciência do solo. Viçosa: Sociedade Brasileira de Ciência do solo, 2000. v.1, p.1-53.

VIEIRA, S. R. Uso da geoestatística em estudos de variabilidade espacial. In: CURSO DE ATUALIZAÇÃO EM CONSERVAÇÃO DO SOLO, 1995. Apostila. Campinas: IAC, 1995. 61p.

WAGNER, L.E.; SCHROCK, M.D. Yield determination using a pivoted auger flow sensor. Transactions of the ASAE, v.32, n.2, p.409-413, 1989.

WARRICK, A.W.; NIELSEN, D.R. Spatial variability of soil physical properties in the field. In: Applications of Soil Physics. New York: Academic Press, 1980. 385 p.

WILD, K.; AUERNHAMMER, H. ROTTMEIER. Automatic data acquisition on round balers. St. Joseph: ASAE, 1994. (Technical Paper Serie, n.94-152)

YULE, I.J.; CAIN, P.J.; EVANS, E.J.; VENUS, C. A spatial inventory approach to farm planning. Computer and Eletronics in Agriculture, v.14, p.151$161,1996$. 
ZAFALON, M. Cafeicultura quer voltar aos bons tempos. Folha de São Paulo, Caderno Dinheiro. p 12,1998. 